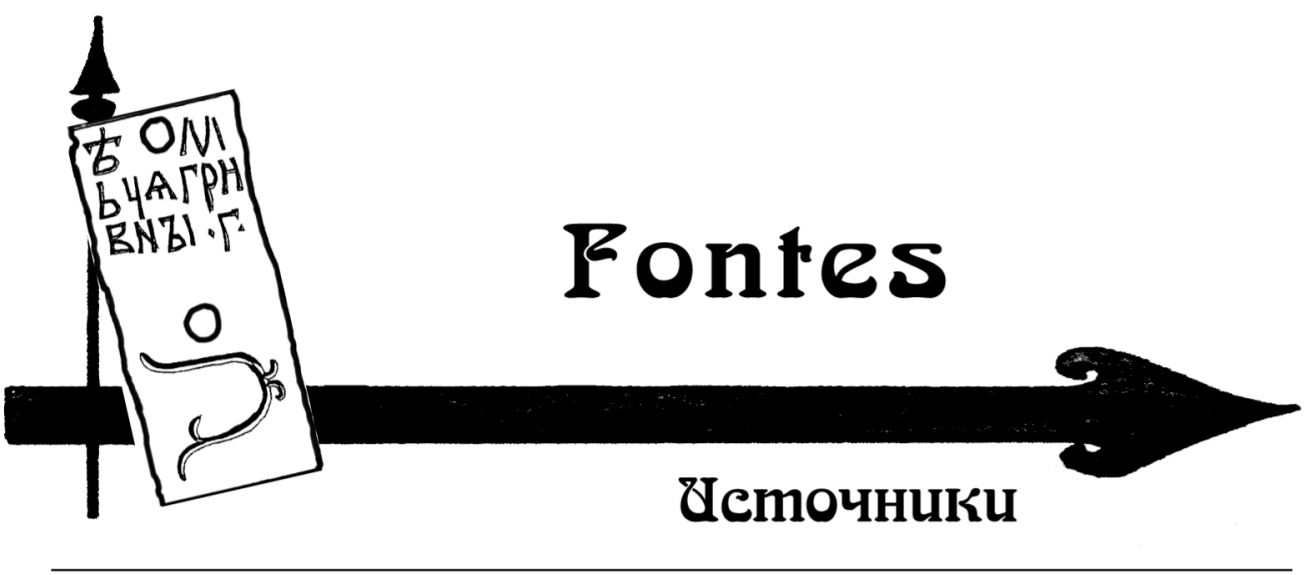

УДК 930, ББК 63.3, DOI https://doi.org/10.21638/11701/spbu19.2019.209

А. А. Бачинский, К. Ю. Ерусалимский, В. Н. Козляков, И. Шварц

ПРОЕКТ РАЗДЕЛА РЕЧИ ПОСПОЛИТОЙ
МЕЖДУ РОССИЕЙ И СВЯЩЕННОЙ РИМСКОЙ ИМПЕРИЕЙ:
КРАКОВСКИЙ СТОЛБЕЦ НАЧАЛА 1576 ГОДА

Столбец московской делопроизводственной скорописи, хранящийся ныне в Библиотеке Чарторыйских (Краков) под шифром Perg. 2822/IX, относится к тому периоду российсколитовских и российско-имперских отношений, за который до нас дошло сравнительно мало источников. Официальное посольское делопроизводство в Москве и Вильно в этот период работало в экстраординарном режиме, поскольку троны Короны Польской и Великого княжества Литовского пустовали, а в Москве рассматривались различные сценарии разделения «наследства» Ягеллонов. Идея раздела Речи Посполитой обсуждалась и в самих Короне и Литве, и в трехсторонних российско-имперско-польско-литовских отношениях, особенно в связи с обсуждением московской и габсбургской кандидатур на предстоящих выборах. Как и при элекции 1573 г., император Максимилиан II и царь

* Работа выполнена при финансовой поддержке Российского научного фонда (проект № 16-18-10091).

(C) А. А. Бачинский, К. Ю. Ерусалимский, В. Н. Козляков, И. Шварц, 2019 
Иван IV планировали участие своих кандидатур или своих сыновей (эрцгерцога Эрнста и царевича Федора). Со стороны Москвы в Короне и Литве долгое время не было определенности насчет участия своего кандидата, тогда как любую имперскую кандидатуру в случае ее прохождения на сейме Иван Грозный поддерживал, о чем было известно и при имперском дворе, и в Вильно. Как именно планировал царь устройство Европы и роль Московского государства в мировой политике в случае прихода к власти в Речи Посполитой Максимилиана II или кого-то из Габсбургов, в Варшаве и Вильно могли догадываться на основе намеков и неоднозначных заявлений московской и венской дипломатии ${ }^{1}$.

Между августом 1574 г., когда Иван Грозный направил к королю Генриху (де Валуа) и Панам раде послания в ответ на миссию Бартоломея Завацкого и Матвея Протасевича (в их числе - тайное послание царя Яну Глебовичу от 23 августа) $)^{2}$, и началом апреля 1575 г., когда было написано послание объединенному Сенату Речи Посполитой, известное сегодня лишь в кратком пересказе «Титулярника» (Москва, 3 апреля 1575 г.) $)^{3}$, в нашем распоряжении нет официальных следов дипломатических отношений между Москвой и Варшавой. Посольская книга по сношениям России с Польшей № 10 открывается материалами более позднего времени, тогда как чистовая документация Посольского приказа в направлении Короны и Литвы за 1571 - начало 1575 г. также ныне неизвестна ${ }^{4}$. После летней переписки 1575 г. в посольской книге также лакуна.

1 Дипломатический контекст см.: Adelung F. Kritisch-literärische Übersicht der Reisenden in Russland bis 1700, deren Berichte bekannt sind. Amsterdam, 1960 (Print). Bd 1. S. 288-309; Материалы к истории Московского государства в XVI и XVII столетиях. Вып. I: Посольство Иоанна Кобенцеля в Москву в 1575-1576 гг. / Изд. Ф. Вержбовский. Варшава, 1896. C. 1-18; Uebersberger H. Österreich und Russland seit dem Ende des 15. Jahrhunderts. Bd 1: Von 1488-1605. Wien; Leipzig, 1906. S. 439-465; Forstreuter K. Preussen und Russland von den Anfängen des Deutschen Ordens bis zu Peter dem Großen. Göttingen; Berlin; Frankfurt, 1955. S. 139-141; Donnert E. Der livländische Ordensritterstaat und Rußland: Der Livländische Krieg und die baltische Frage in der europäischen Politik 1558-1583. Berlin, 1963. S. 134-135, 139; Kappeler A. Ivan Groznyj im Spiegel der ausländischen Druckschriften seiner Zeit. Ein Beitrag zur Geschichte des westlichen Russlandbildes. Frankfurt/M., 1972. S. 46-47, 92-93; Флоря Б. Н. Русско-польские отношения и политическое развитие Восточной Европы во второй половине XVI - нач. XVII в. М., 1978. C. 46-119; Lulewicz H. Gniewów o unię ciąg dalszy: Stosunki polsko-litewskie w latach 1569-1588. Warszawa, 2002. S. 115-284; Ferenc M. Mikołaj Radziwiłł «Rudy» (ok. 1515-1584): Działalność polityczna i wojskowa. Kraków, 2008. S. 399-532; Дубровский И. В. Исследования о дипломатической переписке Ивана Грозного // Русский сборник: исследования по истории России. XXIV: Московия в свидетельствах иноземцев / Отв. сост. тома И. В. Дубровский. М., 2018. С. 138-143.

${ }^{2}$ РГАДА. Ф. 166. ОП. 1. № 14. Л. 103-104; Biblioteka Czartoryskich w Krakowie. № 309. S. 23-26. - См. также публикации: Historica Russiae Monumenta. Petropoli, 1841. T. 1. P. 253-255; Theiner A. Annales Ecclesiastici. Romae, 1856. T. 1. P. 423-424. - Послание Я. Я. Глебовичу опубликовано: Филюшкин А. И. Изобретая первую войну России и Европы: Балтийские войны второй половины XVI в. глазами современников и потомков. СПб., 2013. С. 730-732.

${ }^{3}$ Российский государственный архив древних актов (далее - РГАДА). Ф. 166. Оп. 1. № 14. Л. 109 об.-113. - Данный источник вновь обнаружен Ю. М. Эскиным, М. В. Моисеевым и А. В. Беляковым и нуждается в дальнейшем изучении.

${ }^{4}$ Памятники истории Восточной Европы: Источники XV-XVII вв. T. 7. Посольская книга по связям России с Польшей (1575-1576 гг.) / Сост. Л. В. Соболев. М.; Варшава, 2004 
В начале сентября 1575 г. царь направил Панам раде Великого княжества Литовского послание о коронном тайном агенте Лаврине Дуброве, который, не имея посольского «Глейта» от Сената, уговаривал царя от лица коронных сенаторов вступить с ними в переговоры в обход Панов рады 5 . Одним из условий участия Москвы в избирательной кампании было соблюдение перемирия, и литовская дипломатия добивалась прекращения боевых действий Ивана IV и эрцгерцога Магнуса в Ливонии напрямую в Москве и через Максимилиана II.

На посольство от Максимилиана II рыцаря и ландкомтура Тевтонского ордена Иоганна Кобенцля и дворового советника Даниила Принца к Ивану IV в Вильно возлагали немалые надежды в связи с подготовкой союза Империи и Российского царства на фоне нового бескоролевья в Речи Посполитой после отъезда Генриха де Валуа в Париж в ночь с 18 на 19 июня 1574 г. и серии последовавших затем в 1574-1575 гг. собраний шляхты, призванных обозначить условия новых выборов и запустить королевскую элекцию. 8 ноября 1575 г. под Варшавой собрался сейм, который по причине отсутствия самого короля Генриха и его представителей на этом собрании принял решение о проведении новых выборов. Король, уже на то время правитель Франции, должен был, по выставленным ему условиям, явиться в Речь Посполитую еще 12 мая 1575 г. Его отказ означал, что отныне троны Речи Посполитой были формально свободны. Приступая к выборам на Варшавском элекционном сейме, объединенный Сенат, то есть Коронный Сенат и Панове рада, обратились к Ивану Грозному с призывом соблюдать мирные соглашения 6 . Постановление сейма открывало перед царем широкие перспективы: 19 декабря сенаторы направили ему послание, в котором сообщали об избрании на польский трон императора Максимилиана II: «...и мы уважаючи, а Вашей Милости всказане на доброй бачности маючи, обрали есмо его маистату цесарского наосвеценейшую особу Максимилияна Втораго на королевство Полское и Великое княжство Литовское» ${ }^{7}$. С этим посланием направились в Москву представители Сената и Панов рады Марцин Страдомский и Матуш Нарбут, принятые лишь 2 марта 1576 г. О результатах элекционного сейма Иван IV узнал значительно раньше. Например, ему сообщил о них уже 14-16 января 1576 г. гонец Семен Янглыч Бастанов ${ }^{8}$.

Уже в грамоте, направленной вскоре после этого сенаторам Короны Польской, Иван Грозный ссылается на приход послов от императора и признает планы Империи для себя приемлемыми: «А ныне брат наш, Максимилиян, цесар римский, прислал своих послов Яна Кобенздлю а Даниеля Принцу, хотячи с нами братства и доконченя и соединеня, а сыну бы его Гернесту, архикнязю австрийскому, быти по-вашому обираню на Коруне Полской. А як будеть сын его, Герест архикняз на Коруне Полской и нам бы тогды 3 ним, 3 братом своим, з Максимилияном цесаром и 3 его сыном Гернестом архикня-

(далее - ПИВЕ). Т. 7. С. 17-19 (Панове рада Великого княжества Литовского — Ивану IV. Стенжица, 8 июня 1575 г.).

${ }^{5}$ Archiwum Główne Akt Dawnych (далеe - AGAD). AR. Dz. II. № 3353. S. 1-3 (Иван IV Панам раде Великого княжества Литовского. Москва, 2 сентября 1575 г.).

${ }^{6}$ ПИВЕ. Т. 7. С. $72-74$ (Сенат Речи Посполитой - Ивану IV. Варшава, 2 декабря 1575 г.). ${ }^{7}$ РГАДА. Ф. 79. Оп. 1. № 10. Л. 118 об.-119, публ.: ПИВЕ. Т. 7. С. 89-92. — В «Титулярнике» и Описи архива Посольского приказа начала XVII в. это послание упомянуто с особым в каждом случае указанием на избрание Максимилиана Габсбурга: РГАДА. Ф. 166. Оп. 1. № 14. Л. 113 об.-114 об.; Опись архива Посольского приказа 1626 г. / Под ред. С. О. Шмидта. M., 1977. C. 93.

${ }^{8}$ ПИВЕ. Т. 7. С. $72,81$. 
зем быти в докончани и в соединени на всякого недруга заодин. И вы б, Панове рада, похотели собе и всему хрестиянству прибытка» ${ }^{9}$. Из этого следовало только согласие Ивана Грозного на правление Габсбургов в Короне Польской. В Литву тогда же было направлено письмо другого содержания, ныне известное в целом ряде списков и, по всей видимости, стремительно распространенное современниками в копиях. В этом втором письме слова об избрании Максимилиана II в Короне сопровождаются прямым призывом к литвинам перейти в подданство к царю: «А ныне к нам присылал брат наш Максимилиян цесар, хотечи того, штоб мы з братом своим с Максимилияном цесаром в них докончанье на всякого недруга заодин. А сыну бы его Гернесту арцыкняжати быти на Коруне Полской и на Великом князстве Литовском. А с нами быти ему в докончаню и в соединеню на всякого недруга заодин ${ }^{10}$. И вы б, Панове рада Великого князства Литовского со всею Литовскою землею, похотили нашого на себе господарьства оприч Коруны Полское. А мы у вас господарем быти хотим и на одном Великом князстве Литовском оприч Короны Полское, а справ вашых, волностей и в чом рушити не хотим и во всем по вашому поговору господарем у вас быти хотим и своему господаръству Московскому или своего сына царевича Федора вам на господарьства дати хотим, а на Коруну Полскую взяли бы собе панове рада на королевство Полское цесарового сына Гернеста архыкнязя, а с нами будет брат наш Моксимилиян цесар и сын его Гернест арцыкняз и попа римской и корол ишпанской в докончание и в соединене на всякого недруга заодин» ${ }^{11}$. Эти два текста, как мы увидим, отражают тот же проект, который был с Кобенцлем и Принцем направлен в Вену.

Переговоры царя с имперскими посланниками, в ходе которых возник проект раздела Речи Посполитой, велись уже после того, как в Москву пришло известие об избрании императора Максимилиана на престолы Речи Посполитой. Аудиенция откладывалась, по всей видимости, с целью прояснения обстановки в Короне и Литве. Поездка Кобенцля и Принца в Россию представлена многочисленными источниками, в том числе подробным отчетом Кобенцля и посланием Принца ${ }^{12}$. О подготовке посольства Максимилиан II известил Панов раду еще 8 сентября из Праги

${ }_{9}^{9}$ AGAD. AR. Dz. II. № 105. S. 3. См. также: РГАДА. Ф. 32. Оп. 1. № 3. Л. 142 об.-146. Публикация по списку РГАДА: Собрание государственных грамот и договоров, хранящихся в Государственной коллегии иностранных дел / Изд. на средства Н. П. Румянцева. М., 1894. T. 5. C. 155-156 (Иван IV - Коронному Сенату. Москва, 16-28 января 1576 г.); Памятники дипломатических сношений древней России с державами иностранными (далее - ПДС). Ч. 1. Сношения с государствами европейскими. Памятники дипломатических сношений с империей Римской. Т. 1 (с 1499 по 1594 год). СПб., 1851. Стб. 574-578.

10 Далее зачеркнут повтор «а сыну бы его Гернесту».

${ }^{11}$ AGAD. AR. Dz. II. № 106. S. 2-3 (Иван IV - Панам раде Великого княжества Литовского. Москва, 16-28 января 1576 г.). - См. также списки: GStA PKB. HA. XX. HBA. E. Kasten 720. № VI.28.16; HBA. E. Kasten 719. E5; HHStA. StAbt. AB VIII/7/4. Ost- und Südosteuropa. Rußland I. K. 1. Konv. G. F. 1-3; Rußland I. K. 1. Konv. G. F. 17-19v; ARSI. Provincia Polonia. Epp. Ext. № 27. Р. 79-80v. Публикация: ПДС. Т. 1. Стб. 578-584; СГГД. Т. 5. С. 157-159 (Иван IV - Панам раде Великого княжества Литовского. Москва, 16-28 января 1576 г.).

${ }_{12}$ См.: Adelung F. Kritisch-literärische Übersicht... Bd 1. S. 288-309; Материалы к истории Московского государства в XVI и XVII столетиях. Вып. IV: Донесение Иоанна Кобенцеля 1576 г. / Изд. Ф. Вержбовский. Варшава, 1901. С. I-XII. - См. также: Poe M. Foreign Desriptions of Muscovy: An Analytic Bibliography of Primary and Secondary Sources. Columbus, Ohio, 1995. Р. 97-98 (здесь же библиография вопроса). 
в своем ответе на миссию Андрея Волана от литовских сенаторов. Наказ Кобенцлю и Принцу датирован 26 сентября 1575 г. Миссия началась в середине октября 1575 г. в Праге и направилась через Силезию, Великопольшу, Пруссию и Вильно в Московское государство ${ }^{13} .29$ ноября в Москве было получено из Смоленска сообщение о приезде имперских послов. 30 ноября был выдан наказ приставу о встрече послов на рубеже и отправке с ними в Дорогобуж, где послы были уже 6 декабря и были задержаны до 13 января 1576 г. ${ }^{14}$ Еще в декабре царь обещал, что вскоре приедет в Можайск, тем самым снимая подозрения этикетного характера и позволяя себе потянуть время до получения известий о выборах короля в Варшаве ${ }^{15}$. Первый прием послов состоялся

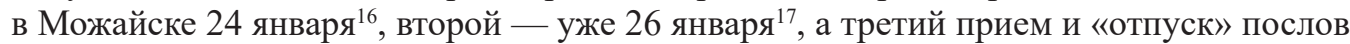
к императору на следующий день - 27 января 1576 г. ${ }^{18}$ Ответ был «устным», то есть речь шла о послании в форме не грамоты, а «речей», о чем позднее царь прямо говорит в послании Максимилиану II от июля 1576 г.: «А в той еси грамоте своей писал к нам брать нашь, что в прошлых днях к вам приехал ваш думца рыцер Ян Кобендъзля, которой у нас был от тебя, брата нашего, посолством с товарыщем своим з Даниелом Принцом. И мы на то ваше послане имь ответь дали. И все то, что мы к тебе, брату своему, изустне приказали, Ян тебе розсказал» ${ }^{19}$. Это значит, что ответ Ивана Грозного на посольство Кобенцля и Принца был, по всей видимости, в форме свитка-столбца, который мог читаться и копироваться, потому что был открыт и не требовал заверения государственной печатью. Оригинал «ответа» Ивана Грозного или одна из его копий хранится в Краковской библиотеке. К вопросу о соотношении Краковского столбца с оригиналом «речей» Ивана Грозного мы вернемся в конце данной статьи.

$$
* * *
$$

Столбец из Библиотеки Чарторыйских, судя по почерку и филиграням, может относиться к началу 1576 г. и заключает в себе обращение Ивана Грозного к импер-

${ }_{13}^{13}$ РГАДА. Ф. 32. Оп. 1. № 3. Л. 51-53 об. (Максимилиан II - Ивану IV. Прага, 26 сентября 1575 г.), 53 об.-54 об. (Карл Австрийский - Ивану IV. Вена, 18 октября 1575 г.); Материалы к истории Московского государства... Вып. 1. Приложения. С. 40-43; Augustynowicz Ch. Die Kandidaten und Interessen des Hauses Habsburg in Polen-Litauen während des Zweiten Interregnums 1574-1576. Wien, 2001. S. 87; Lulewicz H. Gniewów o unię... S. 219; Ferenc M. Mikołaj Radziwiłł «Rudy»... S. 499.

${ }^{14}$ РГАДА. Ф. 32. ОП. 1. № 3. Л. 1-1 об. (см. также Л. 3а-3а об.).

${ }^{15}$ HHStA. StAbt. AB VIII/7/4. Ost- und Südosteuropa. Rußland I. K. 1. Konv. F. F. 58. Московская версия: РГАДА. Ф. 32. ОП. 1. № 3. Л. 27 об.-29 об. - Перевод и публикация: Даниил Прини из Бухова. Начало и возвышение Московии / Пер. с лат. И. А. Тихомиров. М., 1877. С. 50-51. ${ }^{16}$ РГАДА. Ф. 32. Оп. 1. № 3. Л. 44 об. и сл., публ.: ПДС. Т. 1. Стб. 481-482, 503-504, 511.

${ }_{17}^{17}$ РГАДА. Ф. 32. Оп. 1. № 3. Л. 76, публ.: ПДС. Т. 1. Стб. 532.

${ }_{18}^{18}$ РГАДА. Ф. 32. Оп. 1. № 3. Л. 88, публ.: ПДС. Т. 1. Стб. 539. - Ответ был направлен также брату императора Максимилиана, эрцгерцогу Карлу II Австрийскому, который и направил к Ивану IV И. Кобенцля: РГАДА. Ф. 32. Оп. 1. № 3. Л. 198-200, публ.: ПДС. Т. 1. Стб. 613-615 (Можайск, январь 1576 г.). — См. также: Uebersberger H. Österreich und Russland... S. 451; Forstreuter K. Preussen und Russland... S. 139.

${ }^{19}$ РГАДА. Ф. 32. Оп. 1. № 3. Л. 237; Оп. 2. № 5а. - Публ.: СГГД. Т. 5. С. 164-166 (Иван IV Максимилиану II. Москва, июль 1576 г.). Подробнее о данном посольстве см.: Бойцов М. А. Различные взгляды на посольство Ивана IV к императору Максимилиану II в 1576 г. // Средневековая Европа: Восток и Запад. М., 2015. С. 327-364. 
ским послам, переданное им с бывшими «в ответе» Н. Р. Юрьевым, А. Ф. Нагим, дьяками А. Я. и В. Я. Щелкаловыми и И. Дорофеевым. По делопроизводственной форме, столбец был не посольским посланием, а в лучшем случае - приложением к официальному письму или «речами» (с этим связана формула «велел говорити» в начале основной части текста). Официальные послания в виде столбцов отправлять суверенам и другим законным властям было непринято. При этом официальный статус послания очевиден в его формуляре, где полностью приводятся титулы и титульные определения обоих монархов, включая «отчинное» право Ивана IV на Ливонию, которое было вместе с тем одним из предметов переговоров.

Столбец из Библиотеки Чарторыйских (далее также - «Ч») отражает специфику посольских «речей». Сравнение его текста с чистовой версией посольской книги показывает, что послам был выдан список, в котором не размечены слова боярской комиссии. Как между представителями царя на церемонии «ответа» распределялись фрагменты столбца, становится ясно при сравнении списков. Указания на вступление нового говорящего в посольской книге (далее — «П») приходятся в ряде случаев, на те места текста, которые в столбце разделены скрепами. Однако не всегда ${ }^{20}$.

Таблица 1.

\begin{tabular}{|c|c|}
\hline Сставы (Ч) & Боярская комиссия (П) \\
\hline $1-2$ & Н. Р. Юрьев \\
\hline $3-6$ & А. Ф. Нагой \\
\hline $7-12$ & В. Я. Щелкалов \\
\hline $13-15$ & В. Я. Щелкалов, Иван Дорофеев \\
\hline 16 & Иван Дорофеев \\
\hline $17-18$ & Иван Дорофеев, Н. Р. Юрьев \\
\hline 19 & Н. Р. Юрьев \\
\hline $20-21$ & А. Ф. Нагой \\
\hline 22 & А. Ф. Нагой, А. Я. Щелкалов \\
\hline 23 & А. Я. Щелкалов, В. Я. Щелкалов \\
\hline 24 & В. Я. Щелкалов \\
\hline $25-27$ & В. Я. Щелкалов, Иван Дорофеев \\
\hline 28 & Иван Дорофеев \\
\hline $29-31$ & Иван Дорофеев, Н. Р. Юрьев \\
\hline 32 & Н. Р. Юрьев \\
\hline $33-39$ &
\end{tabular}

Принцип разделения слов комиссии по сставам Краковского столбца не соблюден. Начинает и завершает «речи» глава бояр Н. Р. Юрьев. Первые слова говорящих точно разделены границами сставов в Ч. Затем фрагмент «речей», приписанный дьякам В. Я. Щелкалову и Ивану Дорофееву, не находит таких выраженных границ в распределении слов между самими дьяками, как в случае других участников церемонии. Далее в столбце еще однажды граница высказываний совпадает со скрепами между с. 21-22, и в этом случае речь идет о разделении слов между старшими советниками комиссии. Граница между речами дьяков и

${ }^{20}$ ПДС. Т. 1. Стб. 545-567. - Ср.: Приложение. Описание списков приведено в предисловии к публикуемому там же тексту столбца. Сравнение списков проведено нами далее в этой работе. 
Н. Р. Юрьева в конце с. 19 также выразительно обозначена отступом в одну строку. Граница между словами В. Я. Щелкалова и Ивана Дорофеева на с. 28 отмечена только пропуском небольшого фрагмента текста, который читается в П, но в самом Чэта граница не выражена никак - текст возобновляется с той же строки. Можно лишь предположить, что слова дьяков были у каждого из них на столбцах, содержавших копии их общей речи в полном ее объеме, тогда как каждый старший советник имел только столбцы со своей речью.

Помимо Краковского столбца и списка Посольской книги ныне известно еще четыре рукописи, содержащие сходный текст, — это списки Онацевича, Радзивиллов, Дубровского и Венский. Список Онацевича — латинская транслитерация XVIII - начала XIX в. с кириллического текста, сходного с Краковским ${ }^{21}$. В нем нет следов переводческих работ, хотя и есть ряд отличительных особенностей. Во всех приведенных в этой статье текстологических сравнениях список Онацевича сходен с Краковским столбцом, а отличия первого от второго могут рассматриваться как ошибки прочтения, которые при этом не сближают данный поздний список с чтениями известных ранних списков. Примеры разночтений см. в Табл. 2.

Таблица 2.

\begin{tabular}{|l|l|}
\hline \multicolumn{1}{|c|}{ Столбеи Чарторыйских } & \multicolumn{1}{|c|}{ Список Онацевича } \\
\hline Дражайшего и любезньйшего брата нашего (1) & Drażajszeho i lubitelniejszeho Brata naszeho (1 об.) \\
\hline и наше желание исполнити (5) & i nasze żełanije [ucnp. uз żałowanje] spotniti (4) \\
\hline И на том уже договорилос, чтоб (9) & I na tom uże dohoworienoś cztob (5 об.) \\
\hline недружба с королем с свьйским (12) & nedrużba s Korolem Swiejskim (7 об.) \\
\hline $\begin{array}{l}\text { которые крестьяне через немалой час великую } \\
\text { нужу магметцкую терпьли (16) }\end{array}$ & $\begin{array}{l}\text { kotoryje krestjane czerez nemałoj czas nuzu } \\
{[\text { ucnp. uз nuzdu] mahometskuju terpieli (9 об.) }}\end{array}$ \\
\hline И то брат нашь дражайши и любителный (21) & I to Brat Nasz drażajszij i lubitelniejszij (11) \\
\hline $\begin{array}{l}\text { никому иному Лифлянъской земли поступитис } \\
\text { невозможно (26) }\end{array}$ & $\begin{array}{l}\text { nikomu inomu na Liflanskoy zemli postupitiś } \\
\text { newozmożno (14-14 oб.) }\end{array}$ \\
\hline А ныне обрати хотят себъ за господаря (30) & A inyje obrati chotiat sebie za gosudaria (15 об.-16) \\
\hline А иноко слово наше не живет, не так бы было (36) & A inoko słowo nasze ziwet, ne tak by było (18) \\
\hline
\end{tabular}

В Главном архиве древних актов в Варшаве в составе фонда «Архив Радзивиллов» хранится копия с данного столбца под названием «Ответ, данный царем московским Иваном послам императора Максимилиана II» («Odprawa dana przez Iwana cara moskiewskiego posłom cesarza Maksymiliana II»). При первичном описании в Варшавском архиве документ ошибочно датирован 1573 г. Тетрадь из Варшавского архива содержит русско-рутенский список, восходящий к тому же тексту, что и столбец, ныне хранящийся в Библиотеке Чарторыйских, и относится к началу 1576 г. Вторжение местной языковой стихии в передаче московского текста хорошо прослеживается при табличном сравнении сходных чтений. Хенрык Люлевич отметил прямую связь между данным текстом и посольством И. Кобенцля и Д. Принца и указал еще одну копию из собр. П. П. Дубровского 22. Графика данного списка и филигрань бумаги не оставляют сомнений, что он является современной польской копией

${ }^{21}$ Благодарим С. В. Полехова за помощь в работе с данным списком.

${ }^{22}$ Lulewicz H. Gniewów o unię... S. 244. Przyp. 381. - См. также: Ferenc M. Mikołaj Radziwiłł «Rudy»... S. 511. Przyp. 453. - О существовании Краковского столбца Х. Люлевич и М. Ференц ничего в своих работах не пишут. Список Дубровского, написан не просто в «латинской транскрипции», как отметил Х. Люлевич, а на польском языке. 
изучаемого посольского документа ${ }^{23}$. Еще один список, латинский, хранится в Венском архиве и заслуживает текстологического сравнения с остальными (ср. Табл. 3).

\section{Таблицуа 3.}

\begin{tabular}{|c|c|c|c|}
\hline Список Чарт. (Ч) & Список Радзивиллов (Р) & Список Дубровского (Д) & Венский список (В) \\
\hline $\begin{array}{l}\text { что присылали к нам } \\
\text { паны Коруны Поль- } \\
\text { ские и Великого кня- } \\
\text { жества Литовского } \\
\text { до рады присяглого } \\
\text { дияка Михаила Голо- } \\
\text { бурду, чтоб нам быти } \\
\text { у них на господарстве } \\
\text { или сына своего дать } \\
\text { им на господарство. } \\
\text { И мы к ним прика- } \\
\text { зали с Михайлом } 3 \\
\text { Голобурдою, что мы у } \\
\text { них господарем быти } \\
\text { хотим и сына сво- } \\
\text { его на господарьство } \\
\text { дати хотим. А будет } \\
\text { за которым случаем } \\
\text { быть у них нам госпо- } \\
\text { дарем невместно, и } \\
\text { они б никого иного } \\
\text { себе за господаря не } \\
\text { обирали, кроме сына } \\
\text { цесарева Герниста. } \\
\text { А нам то будет любо } \\
\text { таково ж, что будет } \\
\text { на Короне Польской } \\
\text { сын цесарев Гернист, } \\
\text { что и сын наш царе- } \\
\text { вич Федор будет на } \\
\text { Коруне Польской и на } \\
\text { Великом княжестве } \\
\text { Литовском. А будет } \\
\text { похотят литовские } \\
\text { люди опроче Коруны } \\
\text { Польские на Великое } \\
\text { княжество Литовское } \\
\text { нашего над собою } \\
\text { господарьства и мы } \\
\text { им на одно на Великое } \\
\text { княжество Литовское } \\
\text { быти у них хотим (24) }\end{array}$ & $\begin{array}{l}\text { uто присылали к нам } \\
\text { паны Коруны Полское } \\
\text { и Великого князства } \\
\text { Литовского до рады } \\
\text { присяглого дьяка } \\
\text { Михаила Гарабурду, } \\
\text { штобы нам быти у } \\
\text { них на господаръстве } \\
\text { або сына своего дати } \\
\text { им на господаръство. } \\
\text { И мы к ним приказали } \\
\text { Михаилом Гарабурду, } \\
\text { што мы у них господа- } \\
\text { рем быти хотим и сына } \\
\text { своего на господарство } \\
\text { дати хочем. А будет за } \\
\text { которым случаем быти } \\
\text { у них господарем нам } \\
\text { невместьно, и они бы } \\
\text { никого иного собе за } \\
\text { господаря не обирали } \\
\text { окром сына цесарского } \\
\text { Гернеста. А нам то } \\
\text { будет любо таково ж, } \\
\text { што будет на Коруне } \\
\text { Полской сын иесаров } \\
\text { Гернест, што и сын наш } \\
\text { цыревич Федор будет } \\
\text { на Коруне Полской и } \\
\text { на Великом князстве } \\
\text { Литовском. А будет } \\
\text { похотят литовские } \\
\text { люди опроч Коруны } \\
\text { Полское на Великое } \\
\text { князство Литовское } \\
\text { нашого над собою } \\
\text { господаръства, и мы } \\
\text { им на одно Великое } \\
\text { князьство Литовское } \\
\text { быти в них хочем (9) }\end{array}$ & $\begin{array}{l}\text { ze przisylali do nas } \\
\text { panowie s Corony } \\
\text { Polskiey y z Wielkiego } \\
\text { Xięstwa Litewskiego } \\
\text { do rady przisięglego } \\
\text { Pisarza Michala } \\
\text { Haraburdę, zebysmy u } \\
\text { nich na panstwie byli, } \\
\text { abo syna swego na to } \\
\text { dali. Y mysmy do nich } \\
\text { odkazali przes Michala } \\
\text { Haraburdę, ze my u nich } \\
\text { panem bycz chczemy y } \\
\text { syna swego na panstwo } \\
\text { dacz chczemy. A bylo li } \\
\text { by za ktorym trefunkiem } \\
\text { bycz u nich nam panem } \\
\text { nie mozno, y oni aby } \\
\text { nikogo inszego sobie } \\
\text { za pana nie obirali } \\
\text { tylko syna Czesarskiego } \\
\text { Hernesta. A nam to } \\
\text { bendzie tak milo, ze } \\
\text { na Coronie Polskiey } \\
\text { bendzie syn Czesarski } \\
\text { Hernesth, iakoby y syn } \\
\text { nasz Czarewicz Fedor } \\
\text { byl na Coronie Polskiey } \\
\text { y na Wielkim Xięstwie } \\
\text { Litewskim. A zechczą } \\
\text { li litewsczy panowie } \\
\text { bes Corony Polskiey } \\
\text { na Wielkim Xięstwie } \\
\text { Litewskim naszego nad } \\
\text { sobą panowania, y my } \\
\text { im na iednym Wielkim } \\
\text { Xięstwie Litewskim bycz } \\
\text { u nich chczemy (7 oб.) }\end{array}$ & $\begin{array}{l}\text { quod miserant ad nos } \\
\text { Magnates de Regno } \\
\text { Poloniae, et Magno } \\
\text { Ducatu Lith. iuratum } \\
\text { notarium Michaelem } \\
\text { Haraburda, ut nos } \\
\text { apud eos regnare- } \\
\text { mus aut filium nos- } \\
\text { trum illis traderemus. } \\
\text { Nos vero ad illos } \\
\text { renunciavimus, per } \\
\text { Michaelem Hara- } \\
\text { burda, quod nos apud } \\
\text { eos regnare et filium } \\
\text { nostrum tradere volu- } \\
\text { mus. Quod si con- } \\
\text { tingeret aliquo casu } \\
\text { interveniente, nos } \\
\text { regnare apud eos non } \\
\text { posse denunciavimus } \\
\text { ne quemquam alium } \\
\text { pro Domino sibi elig- } \\
\text { erent nisi filium Cesa- } \\
\text { ris Hernestum, quod } \\
\text { nobis tum [Moжrem } \\
\text { yumambcr: tam] } \\
\text { gratum erit, si Reg- } \\
\text { num Poloniae filius } \\
\text { Cesareus Hernostus } \\
\text { obtinebit, perinde } \\
\text { atque si filius noster } \\
\text { Regulus Theodorus } \\
\text { Regnum Poloniae et } \\
\text { Magnum Ducatum } \\
\text { Lith. obtineret. Quod } \\
\text { si magnates Lithuani } \\
\text { volet absque Regno } \\
\text { Poloniae nos in } \\
\text { Magno Ducatu Litua- } \\
\text { niae dominari tum } \\
\text { [ucnp. us tam] sane } \\
\text { nos solo [ucnp. us uno } \\
\text { in] Magno Ducato } \\
\text { Lith. contenti esse } \\
\text { volumus (10v) }\end{array}$ \\
\hline
\end{tabular}

${ }^{23}$ Описание см. во введении к публикации кириллического текста в Приложении. 
Незначительные сепаратные сближения между $P$ и Д, на наш взгляд, не доказывают, что эти два списка имеют особый общий протограф. Польский перевод в ряде случаев лучше передает ранний текст «речей», чем рутенский перевод из Архива Радзивиллов, а следовательно, может быть возведен непосредственно к тексту, сходному с Ч.

Особый интерес представляет латинский список, хранящийся в Венском архиве. В приведенном выше в таблице чтении «ut nos apud eos regnaremus aut filium nostrum illis traderemus» заметно сближение $B$ с Д, где отсутствует «на господарство» русского текста, но сохраняется на его месте конструкция «na to». В латинском списке она также опущена. Источник $B$ выступает в конце латинского перевода, выполненного, по всей видимости, при непосредственном участии интеллектуала и секретаря М. Ю. Радзивилла, Андрея Волана ${ }^{24}$. Вместо фрагмента латинского текста читается польский, на который неожиданно перевод переходит после латинского местоимения «qui», после чего вновь со слов «quibus vero rebus frater noster...» возвращается на латынь (см. Табл. 4).

Таблийа 4.

\begin{tabular}{|c|c|c|c|}
\hline 4 & $P$ & Д & $B$ \\
\hline досчатые & которые & deszkowe & deszkowe \\
\hline доспђхи & доспехи делають, & zbroie robia y axamity & zbroie \\
\hline с петлями & барьхатов с петлями & petliami & axamity \\
\hline двое морхих, да латы & двое морхих, да латы & morchich, & morchich, \\
\hline неметцъкие с рукавы, & немецкие 3 рукавы, & rękawami & eckie \\
\hline которые б нам при- & которые бы нам при- & sie nam dobrze & rękawami ktoreby sie \\
\hline годилися добрые, & годилися добрые, да & zgodzily a & nam dobrze zgodziły \\
\hline пищалей коротких кон- & пищалей & krotkie & a rucznice \\
\hline ских по полуторе пяди & конских по полтори & pultory & konskie po \\
\hline пищал, которые б были & пяди пищал, которые & rucznicza ktoreby byly & piędzi rusznica ktore \\
\hline стенисты и далеко б & бы были стенисты и & czelne y dalieko bili y & by były celne y daleko \\
\hline убивали и стрелять бы & далеко б убивали и & strzeliaczby z nich bylo & y strzelać by $z$ \\
\hline из них было безстрашно & стрелят бы 3 них было & bespieczno ( & nich było bespieczno \\
\hline & & & \\
\hline
\end{tabular}

Сравнение сходных отрывков показывает, что в $B$ появляется отрывок на польском языке, точно совпадающий с Д. Это и свидетельство в пользу того, что польский перевод был готов к моменту включения отрывка из него в латинскую версию, и факт знакомства переписчика латинского текста непосредственно с тем польским переводом, который отразился в Д. При этом ряд текстологических фактов говорят только о развитии первоначальной версии в латинском переводе, не выявляя в последнем более ранних чтений (см. Табл. 5).

Сравнение показывает, что латинский текст и в приведенных примерах развивает особенности польского текста. Ошибочная замена «Сибирския земли» на повтор «Северской земли» в Д приводит создателя $B$ не к восстановлению исходного чтения, а к его полному устранению — то есть в латинской версии просто снят повтор источника, сходного с Д. Еще один вывод, который представляется необходимым из данного сравнения, заключается в том, что русский и польский переводы $(P$ и Д) восходят

${ }_{24}$ См. в Приложении описание данного списка. 
к общему 一 по всей видимости, русскому — протографу, уже содержащему ряд чтений («добре вабителя», «ланкграбя адсицкого»). При этом в ряде случаев Д передает более ранние чтения, чем $P$ (например, имя Ивана Дорофеева).

Таблиия 5.

\begin{tabular}{|c|c|c|c|}
\hline$\Psi$ & $P$ & Д & $B$ \\
\hline $\begin{array}{l}\text { царь казанский, царь } \\
\text { астороханский (1) }\end{array}$ & $\begin{array}{l}\text { цар казанский, цар } \\
\text { астороханъский (1) }\end{array}$ & $\begin{array}{l}\text { Czar Kazanski, Czar } \\
\text { Astrachanski (1) }\end{array}$ & $\begin{array}{l}\text { Rex Casanensis, Rex } \\
\text { Astrachanensis (5) }\end{array}$ \\
\hline $\begin{array}{l}\text { и всеа } \\
\text { земли и ибирские } \\
\text { страны }\end{array}$ & $\begin{array}{l}\text { и всея Сибирењские } \\
\text { земли и Северные } \\
\text { страны }\end{array}$ & $\begin{array}{l}\text { y wszistkiey } \\
\text { ziewerskiey } \\
\text { ziemie y Siewerskiey } \\
\text { strony }\end{array}$ & $\begin{array}{l}\text { et totius terrae Sev- } \\
\text { eriensis }\end{array}$ \\
\hline $\begin{array}{lr}\text { цесаря } & \text { римского } \\
\text { всегда } & \text { брибавителя } \\
\text { неметцкого }\end{array}$ & $\begin{array}{l}\text { цесара римъского } \\
\text { всего добре вабителя } \\
\text { намецкого }\end{array}$ & $\begin{array}{l}\text { Czesarza Rzimskiego } \\
\text { wszego dobra ziczaczego }\end{array}$ & $\begin{array}{l}\text { Imperatoris Romano- } \\
\text { rum }\end{array}$ \\
\hline $\begin{array}{l}\text { тиролского, фарет- } \\
\text { цкого, кибурского и } \\
\text { горетцкого, ланкграбя } \\
\text { алситцкого, монархи } \\
\text { Римского царствия, } \\
\text { бургунского, Вышние } \\
\text { и Нижние земли } \\
\text { люсатцкого, госпо- } \\
\text { даря мархинъского, } \\
\text { склявонского и иных } \\
\text { (2) }\end{array}$ & $\begin{array}{lr}\text { тиролского, } & \text { фарет- } \\
\text { ского, кибурского и } \\
\text { горетского, ланкграбя } \\
\text { адсицъкого, монархи } \\
\text { римъского r цар- } \\
\text { ствия, буръгунского, } \\
\text { Вышнее и Нижнее } \\
\text { земли люсатцкого, } \\
\text { господара мархин- } \\
\text { ского, склявонского и } \\
\text { иных }\end{array}$ & $\begin{array}{l}\mathrm{C} \text { i r o } 1 \mathrm{~s} \mathrm{k} \mathrm{i} \text { e g o, } \\
\mathrm{C} \text { h w a r e c z k i e g o, } \\
\text { Kiburskiego i Horeczkiego, } \\
\text { Langrabia Adsiczkiego, } \\
\text { Monarchi Rzimskiego } \\
\text { kroliestwa, Borhunskiego, } \\
\text { Wysznieyy Nizniey ziemie } \\
\text { Liusaczkiego, hospodara } \\
\text { M a r c h i m s k i e g o, } \\
\text { Sklawonskiego y inych } \\
\text { (1 об.) }\end{array}$ & Tirolis etc. etc. \\
\hline $\begin{array}{l}\text { да Иваном } \\
\text { Дорофђевым }\end{array}$ & $\begin{array}{l}\text { да Иваном Дорофее- } \\
\text { вичом }\end{array}$ & $\begin{array}{l}\text { a Iwanem } \begin{array}{l}\text { Dorofie- } \\
\text { iowy [буква D } \\
\text { читаться: B] }\end{array} \\
\end{array}$ & $\begin{array}{l}\text { et Ioannom Borofie- } \\
\text { iow }(5 \mathrm{v})\end{array}$ \\
\hline $\begin{array}{l}\text { и з Угорские, и з Све- } \\
\text { динские земли с Кор- } \\
\text { ватцкие земли (13-14) }\end{array}$ & $\begin{array}{l}3 \text { Угорское и з } 3 \text { Све- } \\
\text { динское земли из из } \\
\text { с-Корваиъкей земли (6) }\end{array}$ & $\begin{array}{ll}\text { z Węgierskiey } & \text { z } \\
\text { Swedinskiey y } & \text { z } \\
\text { Korwaczkiey ziemi (5) } & \end{array}$ & $\begin{array}{l}\text { ex Ungaria et Cruatia } \\
\text { (8) }\end{array}$ \\
\hline $\begin{array}{l}\text { А будет похотят литов- } \\
\text { ские люди (25) }\end{array}$ & $\begin{array}{lcc}\text { A } & \text { будет } \\
\text { литовские люди (10) }\end{array}$ & $\begin{array}{l}\text { A zechczą li litewsczy } \\
\text { panowie (7 об.) }\end{array}$ & $\begin{array}{l}\text { quod si magnates } \\
\text { Lithuani }(10 \mathrm{v})\end{array}$ \\
\hline $\begin{array}{l}\text { и с Великим княжством } \\
\text { Литовским и с Ливон- } \\
\text { скою землею (27) }\end{array}$ & $\begin{array}{l}\text { и } 3 \text { Великим князь- } \\
\text { твом Литовским и } 3 \\
\text { Ливонъскою землею }\end{array}$ & $\begin{array}{l}\text { y Wielkim Xięstwem } \\
\text { Litewskim y z Iflianskiey } \\
\text { ziemiey (8) }\end{array}$ & $\begin{array}{l}\text { Magnoque } \\
\text { Lith. (11) }\end{array}$ \\
\hline
\end{tabular}

Дальнейшее сравнение списков проведем на выборочном анализе дефектов. Смысловые расхождения между $Ч, P, Д, П$ и $B$ позволяют выявить наиболее ранний текст «речей» и пути его развития в списках (Табл. 6).

Чтение «пресветлый» является формулярным и принятым в протоколе посольских посланий в Москве в это время ${ }^{25}$. Оно сохранилось в Ч и П, а его след - в Д. Список $P$ передает данное место в особой редакции.

${ }_{25}$ Так, оно читается во всех списках как московского, так и литовского происхождения (послания от 12 сентября 1577 г.). См.: РГАДА. Ф. 389. ОП. 1. № 591. Л. 412 об.-413 об.; Ф. 389. ОП. 1. № 592. Л. 21 об.-23; Ф. 79. ОП. 1. Реестр 2. № 1. Л. 25-27 об.; ОР РГБ. Ф. 304. 
Таблица 6.

\begin{tabular}{|c|c|c|c|c|}
\hline$\Psi$ & $\Pi$ & $P$ & д & $B$ \\
\hline $\begin{array}{l}\text { и пресвђтлый и } \\
\text { крайний верх (1) }\end{array}$ & $\begin{array}{l}\text { пресвьтлый } \\
\text { крайний верх (546) }\end{array}$ & $\begin{array}{l}\text { и светльый и край- } \\
\text { ний верх (1) }\end{array}$ & $\begin{array}{l}\text { y przeiasney y } \\
\text { kraini wierzch (1) }\end{array}$ & et praecla \\
\hline $\begin{array}{l}\text { и нам бы людей } \\
\text { своих от рубежа } \\
\text { ливонского отве- } \\
\text { сти (11) }\end{array}$ & $\begin{array}{l}\text { и нам бы людей } \\
\text { своих от рубежа } \\
\text { ливонского отве- } \\
\text { сти }(552)\end{array}$ & $\begin{array}{l}\text { и нам людей } \\
\text { своих от рубежа } \\
\text { ливонского отве- } \\
\text { сти }(5)\end{array}$ & $\begin{array}{l}\text { y nam by liudzi } \\
\text { swych od granicz } \\
\text { I fl i a } \mathrm{n} \mathrm{s} \mathrm{k} \mathrm{i} \mathrm{c} \mathrm{h} \\
\text { odwiescz (4) }\end{array}$ & $\begin{array}{l}\text { atque ut nos exer- } \\
\text { citus nostros a } \\
\text { finibus Lithuaniae } \\
\text { removeamus }(7 \mathrm{v})\end{array}$ \\
\hline $\begin{array}{l}\text { чтоб нам тьх } \\
\text { невЂрных людей } \\
\text { выгнати за Арапы } \\
\text { и до Ази (15) }\end{array}$ & $\begin{array}{l}\text { чтоб нам тьх } \\
\text { невърных людей } \\
\text { выгнати за Арапы } \\
\text { и до Азии (554) }\end{array}$ & $\begin{array}{l}\text { штобы нам тых } \\
\text { неверных людей } \\
\text { выгнати з Арапии } \\
\text { и з Азии (6) }\end{array}$ & $\begin{array}{l}\text { Czoby nam tych } \\
\text { niewiernych liudzi } \\
\text { wygnacz za Arapy } \\
\text { y do Azii (5) }\end{array}$ & $\begin{array}{l}\text { ut istos infideles } \\
\text { homines expella- } \\
\text { mus ex Europa in } \\
\text { Asiam }(8 \mathrm{v})\end{array}$ \\
\hline
\end{tabular}

Важное смысловое отличие обнаруживается в планах изгнать турок, согласно Ч, П и Д, за Аравию в Азию, тогда как в $P$ - из Аравии и из Азии. Составитель латинской версии $B$ не разобрал слово «Арапы» и на его месте обозначил Европу («ех Europa»). Планы Ивана Грозного, с размахом заявленные в тексте столбца, в русском списке приобретают в $P$ наиболее фантастические очертания. Царь в своих сочинениях не раз обращался к идее вселенской империи, вспоминая и права римских императоров на Азию. Так, в Первом послании Курбскому он пишет о границах владений императора Августа: «Како убо Август-кесарь всею вселенною обладаше: Аламаниею и Долматиею и вся Италийская места, и Готфы, и Саврьматы, и Афинеию, и Сириею, и Киликиею, и Ассеею, и Азиею, и Междоречием, и Каподокийскими странами, и Дамаском градом, и Божиим градом Иерусалимом, и Александреею, и Египетская власть, даже и до Перские державы» ${ }^{26}$. Согласно посланию, отправленному царем Иваном князю Александру Полубенскому, Бог одарил Августа «не токмо римскую властию, но и всею вселенною владети, и Готфы, и Савроматы, и Италия вся, и Далматия, и Наталия, и Макидония, и обе Ази, Насия и Сирия, и Междоречие, и Египеть, и Еросалим, и даж до предел Перских» ${ }^{27}$. Говоря о двух Азиях, по всей видимости, Иван Грозный подразумевал земли к востоку от дальних пределов Персии - как и в «Ответе», где Азия расположена за границами Аравии, то есть арабского мира. Можно предположить, что этими «двумя Азиями» царь называл Индию и Китай. В контексте «Ответа», предложение выгнать турок-осман из Азии тоже звучит неуместно, поскольку говорится при этом о восстановлении именно Греческого царства, а не о далекой погоне за разрушителями Византии.

Отличия между Краковским столбцом и посольской чистовой копией не во всех случаях могут быть объяснены обстоятельствами копирования «речей» в Посольском приказе и их первоначальным распределением по отдельным столбцам или сставам.

Доп. II. № 17. Л. 247-249; Ф. 235. Папка 3. № 21. Л. 48 об.-50. - См. публикацию на основе Троицкого списка: Филюшкин А. И. Изобретая первую войну... С. 738.

${ }^{26}$ Ср.: ПИГАК. С. 21 (Иван IV - А. М. Курбскому. Москва, 5 июля 1564 г.). — Реконструкция цитаты в основном тексте авторов статьи.

${ }^{27}$ ОР РГБ. Ф. 304. Доп. ІІ. № 17. Л. 221-235 (здесь: Л. 226 об. -227). - См. также: ОР РГБ. Ф. 235. Папка 3. № 21 (Бумаги Попова. № 47). Л. 32-40 об. (копия ХІХ в.). Публ.: Послания Ивана Грозного / Подгот. текста Д. С. Лихачев, Я. С. Лурье. М.; Л., 1951. С. 197-204, 644-645 (Иван IV — А. И. Полубенскому. Псков, 9 июля 1577 г.). — Реконструкция цитаты в основном тексте авторов статьи. 
В ряде случаев речь может идти о сознательном изменении общего протографа. По всей видимости, прагматическими соображениями объясняется устранение в тексте столбца читающихся в посольской книге слов от имени царя с предложением императору Корону и Литву «войною кручинити». Замена фрагмента о том, сообщить или нет имперским послам содержимое грамот царя сенаторам Речи Посполитой и кому везти грамоты «к Паном к своей братье», заставляет полагать, что в московском делопроизводстве отразилась особая версия «речей», в которой сглажены те аспекты переговоров Ивана IV с Кобенцлем и Принцем, которые в Москве считали важным не афишировать ${ }^{28}$. Однако расхождения между версией Краковского столбца и Посольской книги позволяют предположить, что в Москве допускали возможность ознакомления польской и литовской стороны с содержимым «речей», отправленных императору Максимилиану II.

Таким образом, списки Ч и П восходят к общему протографу, тогда как $O, P$ и Д восходят к протографу, сходному с $Ч$, независимо друг от друга. Изначальное хранение $Ч$ и $P$ в архиве Радзивиллов и перевод столбца Кобенцля и Принца с московского языка на местный русский язык свидетельствует о том, что канцлер Великого княжества Литовского М. Ю. Радзивилл Рыжий был из первых рук ознакомлен с проектом Ивана Грозного, направленным в Вену в конце января 1576 г. $^{29}$

Приведенные выше сравнения списков показывают, что Краковский столбец - ценный источник для истории восточноевропейской дипломатии, составлявший первоначально основной «ответ» Ивана Грозного императору Максимилиану II. Упомянутые в «речах» события, предшествовавшие переговорам с И. Кобенцем и Д. Принцем, известны по другим источникам.

$* * *$

Перейдем к содержимому посольских «речей» конца января 1576 г. Царь напоминает послам, что император не присылал в Москву свое великое посольство из-за мирных переговоров Дании и Швеции, затянувшихся из-за разногласий обеих стран по Ливонии. Это было еще до смерти польского короля Сигизмунда II Августа, то есть до 7 июля 1572 г. Император еще до этого события обсуждал «с неметцкими радами» возможность отправить послов в Москву, но смерть короля прервала и эти инициативы. На место Сигизмунда II Августа был избран Генрих де Валуа, но и он вскоре «покинул» Польское королевство. По этим причинам император Максимилиан так и не прислал своих послов к царю. Впрочем, все это происходило «против воли» императора, а миссия Никона Ушакова, Магнуса Паулуса и Григория Вестфалуса от царя Ивана закончилась неудачей - посланники были захвачены шведским королем Юханом III $^{30}$. Никон на тот момент в Москву не вернулся. А дружественное послание от Ивана Грозного было доставлено Максимилиану II «в прошлом году июля 26 дня», то есть 26 июля 1574 г. Император извещал царя со своими послами, что хотел бы прислать к нему «великое» посольство, но сначала должен обо всем посоветоваться «с своими радами и всеми князи» на «зборе», то есть на рейхстаге, который должен был состояться в ближайшее время. Послы принесли царю Ивану сообщение о «любви и братстве».

${ }_{28}$ Данные места отмечены нами в публикации текста. См.: Приложение.

${ }^{29}$ См. Стемму к данной статье.

${ }^{30}$ Ерусалимский К. Ю., Швари И. Миссия Ждана Квашнина в Священной Римской империи: К истории российско-имперских отношений XVI века // Studia Slavica et Balcanica Petropolitana. 2018. № 1 (23). C. 21-54. 
Возвращаясь к актуальной политике, Иван Грозный повторял уже в который раз, что поддерживает кандидатуру эрцгерцога Эрнста на троны Короны и Литвы. В случае победы Эрнста Габсбурга на элекции царь готов был соблюдать мир и заключить с ним военный союз. Царь уже знал о результатах Варшавского сейма, склонившегося, по его сведениям, к кандидатуре Максимилиана II, однако были опасения, что решение под влиянием каких-то «людей упрямых» поменяется, а кроме того, следовало спешить воспользоваться этими результатами, поскольку все еще оставались опасения, что прежний король вернется на свой трон. Эти сентенции царя точно отражают тот уровень знаний, который доступен был Москве в конце 1575 - начале 1576 г. $^{31}$

Иван IV знал от Кобенцля и Принца, что по пути в Россию «через Литву» они встречались с тремя какими-то местными панами, которые собирались «в Польшу на совет», то есть, по всей видимости, в Варшаву. О результатах съезда царь Иван уже знал, полагая, что там договорились избрать на трон эрцгерцога Эрнста. Царь получил от Панов рады сообщение с предложением мира. Возможно, слова о нем соответствуют одному из недошедших до нас посланий от лица объединенного Сената Речи Посполитой, предложившего российскому монарху заключить договор о мире и военном союзе «против всех недругов». Как видно, уже на пути к царю у имперских послов завязались тайные отношения с местными сановниками. С кем именно - они не сказали.

Император выстроил переговорную тактику вокруг Ливонии, настаивая, чтобы царь отвел войска от ее пределов. Слухи о нападении в январе 1575 г. на Пернов и Колывань царь не опровергает, но настаивает, что Юрьев взят у Ордена «за их грубость», а борьба за Колывань - результат его противостояния с Юханом III. Свои старые соглашения с Империей царь обязуется выполнять и дальше, но это значит, что свои интересы в Ливонии он считает незыблемыми. Короля Ливонии эрцгерцога Магнуса упоминает при этом как своего вассала ${ }^{32}$. Приход к власти в Речи Посполитой эрцгерцога Эрнста Иван Грозный напрямую увязывает с желанием укрепить свои позиции в Ливонии, хотя прямо нигде в столбце о последствиях воцарения Габсбургов в Короне и Литве для решения Ливонского вопроса не говорится. Ясно, что царь не мог преодолеть сопротивления имперских сословий и самого императора в Ливонском вопросе, и стремился выторговать наиболее выгодные для себя условия. Достигал он этого, намекая императору, что в переговорах с М. Б. Гарабурдой отрекся от кандидатуры своего сына Федора на выборах в пользу Габсбургов. Таким образом, царь «уступал» Корону Польскую и Великое княжество Литовское императору Максимилиану II.

Сделка требовала ответных уступок. Всю Ливонию вместе с Курляндией Иван IV считает своей. Великое княжество Литовское во владениях Габсбургов царь также гарантировал в границах uti possidetis, но Киев с округой — на свою сторону. В обмен на утверждение крестного целованья своего отца, великого князя Василия III, всех своих завоеваний в Великом княжестве Литовском, Киев и Ливонию царь готов был выступить в Христианской лиге вместе с Империей, и в составе Лиги - с Венгрией, Веной, Хорватией, Испанией, папой римским и другими христианскими государствами

${ }_{31}$ Флоря Б. Н. Русско-польские отношения... С. 113-118; Augustynowicz Ch. Die Kandidaten... S. 153-155; Lulewicz H. Gniewów o unię... S. 243-244.

${ }^{32}$ Возможно, в те же дни, когда составлялся «ответ» имперским послам, Иван Грозный направил послание королю и эрцгерцогу Магнусу о приходе и отпуске послов от императора. См.: РГАДА. Ф. 32. Оп. 1. № 3. Л. 139-141 (Иван IV — Магнусу. (Москва), январь 1576 г.). 
против Османской империи. Как результат - неверные будут изгнаны «за Арапы и до Ази». Ислам также будет повержен. Все Греческое царство «на всход солнца» вернется к христианским государям, под которыми в узком смысле Иван IV считает себя и своих детей. Таким образом, и плоды Лиги должны были восстановить Греческое царство во владениях православного императора из Москвы.

Все самые радужные проекты были открыты в будущем только в том случае, если бы на троны Речи Посполитой взошли Габсбурги, а поддерживать их царь соглашался, рассчитывая на мирное соглашение и раздел спорных территорий. Кроме того, он видел необходимость в том, чтобы отговаривать часть польских панов от других кандидатов. Имя Стефана Батория («по присылке турского салтана воеводу семиградцкого») прямо звучит в Столбце. И поскольку главным противником грядущей Христианской лиги царю видится Турция, а ее ставленником Иван IV считает трансильванского правителя, можно полагать, что угроза потери польского трона для Габсбургов рисовалась царем еще и как угроза его перехода в руки вассала Османской империи. Победа Батория в глазах царя Ивана означала бы последующее географическое разделение христианского мира Турцией и ее вассалами и угрозу для обеих частей христианского мира в будущем. «Упрямые люди», стоящие на пути реализации проекта царя, как раз во второй половине января 1576 г. собрались в Енджееве, провозгласили о победе на выборах кандидатуры Стефана Батория и назначили на 4 марта его венчание с Анной Ягеллонкой и коронацию королевской четы ${ }^{33}$.

В роли спасителя христианства Иван Грозный отвечал согласием и на предложение призвать польскую и литовскую шляхту отказаться от иных кандидатур в пользу Эрнста Габсбурга. От императора в сложившихся условиях в Москве ожидали скорейшей присылки великих послов, в числе которых надеялись увидеть «удельных князей», то есть кого-то из подвластных Максимилиану II правителей Империи, его родичей. Одновременно царь хотел форсировать первоочередные задачи: достичь согласия по Ливонии, изгнав оттуда Швецию, признать несправедливыми статусные требования шведского короля (прежде всего, его стремление возвыситься над новгородскими наместниками, которых Иван Грозный считал ему ровней), вернуть из Швеции посланника к императору Никона Ушакова.

Царь отказывался рассылать гонцов с письмами, считая саму практику развоза писем от царя бесчестной, однако соглашался в посольских грамотах убеждать Панов раду в пользу Габсбургов. Впрочем, в финальной части послания раскрывается подлинная краткосрочная программа действий царя, вступающая в противоречие с вышеизложенными уступками. Иван Грозный планировал агитировать Великое княжество Литовское в свою сторону, а Корону Польскую - за Габсбургов, и только в случае отказа литвинов от своей кандидатуры допускает правление Эрнста Габсбурга и в Великом княжестве Литовском, но на условиях, которые были приведены выше и неизбежно вели к сокращению его государственной территории ${ }^{34}$.

${ }_{33}$ Dubas-Urwanowicz E. Koronne zjazdy szlacheckie w dwóch pierwszych bezkrólewiach po śmierci Zygmunta Augusta. Białystok, 1998. S. 199-209.

${ }^{34}$ Об этом см. также: Лурье Я. С. Новые данные о посольстве Сугорского и Арцыбашева в 1576 г. // Исторические записки. 1948. № 27. С. 298; Donnert E. Der livländische Ordensritterstaat... S. 139. Anm. 222. 
Важным фактором в переговорах о власти в Великом княжестве Литовском и Короне Польской стало появление «речей» Ивана Грозного во владениях Великого княжества Литовского. Оригинал, который был передан в январе 1576 г. имперским послам, сегодня не известен, а вопрос о его соотношении с Краковским столбцом требует специального исследования с учетом того, что в Вене сохранился латинский перевод, выполненный, как мы показали, по всей видимости, именно с польского перевода. Нельзя исключать, что другой версии, помимо Краковского столбца, в распоряжении послов и не было. Однако это лишь догадка. Можно предположить, что Иоганн Кобенцль и Даниил Принц (а вероятнее - один Кобенцль) добровольно отдали оригинал или одну из русских копий «речей» Ивана IV властям Речи Посполитой. Однако кому именно?

Незадолго до имперских представителей в Литву приехал гонец царя Лука Новосильцев $^{35}$. В первой половине февраля Л. 3. Новосильцев и И. Кобенцль вели переговоры в Вильно, откуда в конце февраля российский посланник направился на переговоры в Корону Польскую. Вероятно, в начале февраля литвинам и стал известен текст «Ответа» Ивана Грозного Максимилиану II ${ }^{36}$. Пока в Империю из России шло посольство кн. 3. И. Сугорского и А. Г. Арцыбашева, к которому в мае присоединился в Дерпте Д. Принц, в столице Великого княжества Литовского обсуждались результаты посольства в Россию и проект Ивана Грозного, изложенный в «Ответе». Вновь при посредничестве секретаря литовского канцлера, Андрея Волана, император был оповещен об ответе Ивана Грозного, а 13 марта 1576 г. в Вену вернулся Кобенцль ${ }^{37}$. Судя по тому, что в Венском архиве отложился перевод Волана, составленный с упущением целого отрывка (который так и остался непереведенным с польского языка), интерес к деталям ответа Ивана Грозного был незначительным. Политическая конъюнктура в Короне и Литве увела события далеко от начала года, когда кандидатура самих Габсбургов на польском троне еще не была такой шаткой.

Иной была реакция литовской политической элиты. Панове рада должны были задуматься, насколько перспектива объединения Москвы и Вены была приемлема с точки зрения и без того убывшей после Люблинской унии территории Великого княжества Литовского. В Литве и Короне перспектива утратить спорные русские земли, Киевское воеводство и Ливонию в случае победы московского или венского кандидата на выборах должна была еще больше отвратить и Панов раду, и местную шляхту от московского правителя. Не случайно уже в послании от 19 февраля 1576 г. Панове рада давали понять царю, что несмотря на раскол в рядах шляхты и переход части избирателей на сторону Стефана Батория, разделение Речи Посполитой

${ }^{35}$ ПИВЕ. Т. 7. С. 71-72, 81, 105.

${ }^{36}$ Материалы к истории... С. 52; Lulewicz H. Gniewów o unię... S. 241-242, 244-246. — Как отметил Х. Люлевич, отдельные фрагменты проекта Ивана Грозного Я. Я. Глебович упоминает уже в своем письме Я. И. Ходкевичу от 3 февраля 1576 г., но в качестве догадки. Опорой для мнения Глебовича могли служить предыдущие предложения царя, из которых польский исследователь особенно выделяет предложения, направленные царем в Вильно с М. Б. Гарабурдой еще в начале января 1573 г.

${ }^{37}$ См. также: Schellhaß K. Zur Legation des Kardinals Morone (1576; Moskau, Bayern) // Quellen und Forschungen aus Italien. Archiven und Bibliotheken. 1910. № 13. S. 317-319 (И. Кобенцль - Максимилиану II. Вена, 13 марта 1576 г.). 
невозможно ${ }^{38}$. Царь не терял надежд на то, что сложная обстановка разрешится в пользу какого-нибудь из его проектов. В марте, ожидая посольства от императора, он обещал Короне и Литве соблюдать мирные соглашения. На сей раз царь обращался к единому Сенату Речи Посполитой ${ }^{39}$. Значит ли это, что царь уже к тому времени отказался от своего плана отторжения Великого княжества Литовского от Короны Польской?

Литвины к тому времени знали содержание тайного «ответа» Ивана Грозного Максимилиану II. Нельзя исключать, что по каким-то причинам «ответ» царя Ивана, имевшийся в распоряжении имперских послов, просочился независимо от их воли. Однако более вероятным представляется, что император Максимилиан II, поставив сенаторов Речи Посполитой в известность о планах царя, пытался отстоять свое избрание, гарантируя Короне и Литве, что московский проект выполнен не будет ${ }^{40}$. Более того, судя по посланиям царя сенаторам Короны и Литвы от второй половины января 1576 г., Иван Грозный не скрывал общего абриса своего плана раздела Речи Посполитой между Империей и Московским государством, и этим могут объясняться особенности Краковского столбца, которые отличают его от посольской версии «речей». Современные событиям русская, польская и латинская версии содержат немаловажные особенности, они не транслируют первоначальный текст, но развивают его в заданных направлениях. Проведенное исследование показало, что все три версии созданы в окружении канцлера Великого княжества Литовского М. Ю. Радзивилла. При этом в русской и латинской гипертрофированно изображено стремление Ивана IV изгнать осман не только «в Азию», но и «из Азии» (рус.) или «из Европы» (лат.). Латинская версия, созданная на основе польской, отличается от своего источника тем, что как бы лишает Ивана IV царского титула - его титул «царь» (ср. в польск. «Сzar») передан в латинской версии, направленной из Вильно в Вену, как королевский: «Rex».

Проект Ивана Грозного оценивался руководством Великого княжества Литовского как угроза для государственного суверенитета, и как результат - М. Ю. Радзивилл и другие литовские сенаторы предприняли осмысленные шаги по разоблачению планов Москвы. Было понятно, что результаты выборов на Варшавском сейме в декабре 1575 г. были для реализации проекта царя Ивана Васильевича лишь начальным стимулом. Этот результат он считал приемлемым только в том случае, если бы император признал законными претензии московской власти на Ливонию, все завоевания Москвы в Великом княжестве Литовском и на Киевское воеводство. По сути, как следует из сравнения проекта, направленного Максимилиану II, с посланием Ивана Грозного в Великое княжество Литовское, царь вел двойную игру, стараясь перетянуть литвинов

${ }_{38}^{38}$ ПИВЕ. Т. 7. С. 100-102 (Панове рада Великого княжества Литовского (Я. И. Ходкевич) Ивану IV. Вильно, 19 февраля 1576 г.). См. также: АЗР. Т. 3. С. 185-186 (дата «21 февраля 1575 г.» ошибочна), то же: ПИВЕ. Т. 7. С. 98-99, то же: Akta zjazdów stanów Wielkiego Księstwa Litewskiego. T. I: Okresy bezkrólewi (1572-1576, 1586-1587, 1632, 1648, 1696-1697, 1706-1709, 1733-1735, 1763-1764) / Oprac. H. Lulewicz. Warszawa, 2006. S. 158-159 (Панове рада Великого княжества Литовского - Ивану IV. Вильно, 21 февраля 1576 г.); ПИВЕ. Т. 7. С. 99-100 (М. Ю. Радзивилл - Ивану IV. Вильно, 21 февраля 1576 г.).

${ }^{39}$ ПИВЕ. Т. 7. С. 92-96. См. также списки: РГАДА. Ф. 389. Оп. 1. № 217. Л. 18 об.-22; Ф. 166. Оп. 1. № 14. Л. 114 об.-116 об.; Biblioteka Kórnicka PAN w Kórniku. № 1537. К. 67-69 (Иван IV - Сенату Речи Посполитой. Городок, (12) марта 1576 г.).

${ }^{40}$ См. также: Augustynowicz Ch. Die Kandidaten... S. 127-129. 
полностью в состав Московского государства. Схождения в содержании проектов не отменяли значительных различий между ними. Литвинам царь гарантировал вечный христианский мир в случае их перехода в подданство царя, тогда как императору рисовал масштабные перспективы отвоевания Греции, полного уничтожения Турции и, по сути, разделения мира на две мирных христианских империи. Оба эти проекта рухнули, однако их влияние на дипломатическую обстановку в восточной и центральной Европе еще требует своих исследований.

\section{ПРИЛОЖЕНИЕ}

Краковский столбец - Краков. Biblioteka ks. Czartoryskich w Krakowie. Rkps 2822/IX. Данный столбец выступает под номером IX в собрании свитков («Zwoje»), хранящемся на 2018 г. в отдельной коробке, где всего 18 столбцов XVI-XVII вв. (самый поздний из датированных выступает под номером III - это челобитье стрельцов царю Алексею Михайловичу от октября-ноября 1674 г.). По информации, полученной от сотрудников Библиотеки, около 23 июня 2010 г. столбцы изучал и описывал литовский исследователь Элмантас Мейлус (Elmantas Meilus). Наше описание уточняет наблюдения коллеги. Столбец состоит из 39 сставов (38 соединений-«скреп»), общий размер ок. 12108×143 мм. В публикации принята сквозная нумерация сставов. На лицевой стороне вверху справа подклеена полоска бумаги, выступающая за правый обрез столбца, с чернильным номером: «12351» (на обороте подклейки). На обороте сверху по центру черными чернилами нынешний шифр: «2822/IX». Под ним, как указал нам сотрудник Библиотеки Павел Прокоп, размытый штемпель Библиотеки Чарторыйских. Ниже чернильная пометка архива Радзивиллов, ориентацией сверху вниз: «№ 1. Fasc. 7. Publicznych». Фрагменты водяных знаков обнаружены на 7 сставах столбца, все - от левого поля. Филиграни: 1) Сфера под 5-конечной звездой (с. 15). От знака сохранились звезда и начало обода с перегородкой. Ср.: Теcnicelpa. № $76 .-1564$ г. ${ }^{41}$; 2) Литеры B / S (зеркальная S), между ними - цветок (с. 35). Ср.: Piccard-Online. № 30691. - 1565 г..2; 3) Перчатка. Сохранилось лишь два фрагмента, оба с четырьмя пальцами (без большого), отделенными перегородкой от ладони, и 5-конечной звездочкой. Знак - между двух понтюзо (с. 36, 37). Cp.: Piccard-Online. № 155753. - 1563 г.43; 4) Близкий, но более ровный вариант знака Перчатка, сходного с № 3 (с. 33); 5) Кувшин без подставки, с лилией в нижней части тулова и литерами VI (c. 31, 32). Аналог не обнаружен. Писано московской деловой скорописью XVI в. Текст - московский список.

Список Посольской книги - Москва. Российский государственный архив древних актов. Ф. 32 (Сношения с Австрией и Германской империей). Оп. 1. № 3. Л. 99 об.-131 об. Текст - чистовой московский список «речей». Списку «речей» предпослано заглавие с отступом в 1 строку: «А се таков отвђт дан цесаревым Максимилияновым послом Яну Кобендзль да Даниелу Принцу» (л. 99 об.).

${ }^{41}$ Cм.: URL: http://memoryofpaper.oeaw.ac.at/tecnicelpa/images/4358.jpg (дата посещения 30.09.2018).

${ }^{42}$ CM.: URL: https://www.piccard-online.de/detailansicht.php?klassi=025.029\&ordnr=30691\&sp rache $=$ (дата посещения - 30.09.2018).

${ }^{43}$ CM.: URL: https://www.piccard-online.de/detailansicht.php?klassi=019.002.009.007\&ordnr=1 $55753 \&$ sprache $=($ дата посещения - 30.09.2018) . 
Список Архива Радзивиллов - Варшава. Archiwum Główne Akt Dawnych. Archiwum Radziwiłłów. Dz. II. № 89a. Тетрадь (не сшитая) на 8 л. ок. $321 \times 214$ мм. Бумага повреждена, особенно у корешка по центру, восстановлена при помощи прозрачных заклеек. Была согнута по вертикали от края и корешка, ок. 25 и 35 мм соответственно - для создания рабочей страницы. По горизонтали был свернут вчетверо (3 сгиба). Пагинация архивная карандашная на 16 с. (регистрация - на с. 16). На с. 1 в левом верхнем углу шифры. Старые «65» и правее «[126]» зачеркнуты (2-й - карандашом, 1-й - алым карандашом). Ниже алым нынешний шифр: «89a». Еще ниже штемпель: «AR, dz. II». Ниже на левом поле - штемпель AGAD. Он же - на с. 16 под регистрацией. Правее на верхнем поле карандашом: «1573 r., marzec». На с. 16 во 2-м квадрате, ориентация от внешнего поля к корешку: «Odprawa Kniazia Mos/kiewskiego dana Posłom / Cesarza Maximiliana / ktory prosił o to aby / oni instantią swą / wsparli Ernesta / Syna Cesarskiego / y na Krolewstwo / Polskie promo/wowali», чуть ниже левее: «22». В том же сегменте листа у корешка с такой же ориентацией более темными чернилами шифр архива Радзивиллов, частично под заклейкой у корешка: «№ 1. Fasc. 38. Publicznych». Номер фасцикула просматривается плохо. Филиграни ${ }^{44}:$ 1) Лилия с литерами I/B ок. 43 мм на л. $1=8,2=7$. Ср.: Лауцявичюс № 2096. - 1578 г.; 2) Литера W ок. 47 мм на л. 3=6, 4=5. Ср.: Лауцявичюс № 1040. - 1589, 1590 гг. Деловая скоропись Великого княжества Литовского. Текст - русский список.

Список Дубровского - Санкт-Петербург. Отдел рукописей Российской национальной библиотеки. Коллекция П. П. Дубровского. Авт. 152. № 1. 11 л. Хранится в картонной папке с ткаными завязками с печатным текстом в печатной рамке в левом нижнем углу папки: «Государственная публичная библиотека им. Салтыкова-Щедрина. / ОТДЕЛ РУКОПИСЕЙ / Фонд № Опись №Ед. хр. №» (аналогичный штемпель, но ориентацией верхом вниз в правом верхнем углу папки). Под рамкой в левом нижнем углу текст: «тип. ГПБ з. 1113 т. 3000». Посередине папки типографский печатный текст: «Фонд» и несколько пустых строк для заполнения, в них следы затертой рукописной надписи синими чернилами, поверх них надпись чернилами такого же цвета: «Нем. Fv. XIV № 2». Под ним типографический текст: «Листов» (и свободное поле над линией для заполнения). На корешке папки наклейка из белой бумаги на высоте 56 мм от верхнего края, высота наклейки 25 мм, ширина 30 мм. На наклейке двойная рамка, в ней надпись: «Немецк. Fv. XIV № 2». Размер папки ок. 370×263 мм. Тетрадь (не сшитая) на 11 л. ок. 333×212 мм. Тетрадь образуют согнутые пополам листы (т. е. листы сдвоены) вдвое большей ширины. Л. 11 одинарный, приклеен к л. 10 прозрачной склейкой. Пагинация теми же чернилами, что и основной текст до л. 5 посередине нижнего края страницы. Архивная пагинация черными чернилами в правом верхнем углу листа на всех страницах. Более поздняя архивная пагинация карандашом на всех листах в левом нижнем углу, кроме л. 1 (более крупная в правом нижнем углу), на л. 10 карандашная пагинация продублирована более крупно в правом нижнем углу. На л. 1 также присутствуют дополнительные пометки карандашом: «№ 1» в левом нижнем углу и «77»

44 Здесь и далее использованы альбомы: Laucevičius E. 1) Popierius Lietuvoje XV-XVIII a. Vilnius, 1967; 2) Popierius Lietuvoje XV-XVIII a. Atlasas. Vilnius, 1967. 
посередине нижнего края. На 1 и 8 листах штемпель Императорской библиотеки (ИБ в венке под короной). Правое поле ок. 30 мм, левое ок. 10 мм, верхнее ок. 22 мм, нижнее ок. 28 мм. Рабочее поле ок. 172 мм. Основной текст на обеих сторонах листа до л. 11. На л. 11 об. приписка теми же чернилами, но, возможно, другим почерком: «Respons kniazia vielkiego Miskiewskiego przez / swoie boiary poslom cesarza Maximiliana [далее смазаны два слова, более насыщенными чернилами] ро / Henryku fran/cuzie [слово может быть дописано, более серый оттенок чернил, чем основной светло-коричневый]». Филигрань - Гербовой щит с мечами под короной. Ср.: Briquet №1421. - 1579 г. ${ }^{45}$ Текст — польский список.

Венский список - Вена. HHStA. StAbt. AB VIII/7/4. Ost- und Südosteuropa. Rußland I. Karton 1. Konv. G. F. 5-16v. Тетрадь на 12 л. Развернутый лист 415 (420) × 326 (332) мм. Бумага согнута по горизонтали для создания рабочей страницы. Пагинация архивная в правом нижнем углу. На л. 5 в левом верхнем углу помета карандашом: «(1576) 29 Jänner», внизу слева: «(Russica)». На каждой странице в левом верхнем углу штемпель Венского архива. На л. 14 об. более темными чернилами после основного текста приписка: «Haec ex originalibus l-ris Moscovitico / idiomate scriptis, de verbo ad ver/bum sermone latino reddita sunt / ex mandato ill-mi principis Domini / Nicolai Radivilli palatini Vilnen. / et cancellarii Magni Duc. Lith.: per / me Andream Volanum celsitudinis / suae secretarium». Листы 15-15 об., 16 - чистые. На л. 16 об. помета: «Der Großfürsten/decret oder schrifft/ licher bescheid uns / den 29 Janua(rii) hiro / umb mittag gegeben». В тексте подчеркивания, штрихи-выделения и глоссы на полях более темными чернилами почерком, отличным от основного текста: «Archi/tecti. / Artifi/ces» (л. 14). Филигрань - Jelita в фигурном щите. Ср.: Лауцявичюс № 1510. - 1561 г. Текст - латинский список.

Список Онацевича - Санкт-Петербург. Институт русской литературы РАН (Пушкинский дом). Древлехранилище. Колл. 50 (И. С. Онацевич). Папка 8. № 23. 20 л. Список XVIII в. на разлинованной карандашом и отчеркнутой от внешнего края писарской бумаге. Пагинация не проставлена, принимается нами условно. В каталоге коллекции данная единица хранения обозначена: «Копия грамоты Ивана Грозного к Максимилиану II о выборах польского короля». Текст - латинская транслитерация кириллического списка. На полях и между строк пометы с переводом отдельных слов на польский язык, выделениями фрагментов и подчеркиваниями.

В публикации сохраняем ять (њ), все остальные буквы стандартизируем по нормам алфавита наших дней. Титла раскрываются. Концевая ер (ъ) не учитывается. Не комментируются частичные утраты и восстановления писцом фрагментов букв на последних и первых строках сставов. Все знаки препинания привнесены публикаторами. Утраченные и поврежденные фрагменты у правого поля столбца реконструируются в квадратных скобках (курсивом - по смыслу). В ряде случаев учитываются отличия текста от списка Посольской книги («П»), который используется также для реконструкции утраченных чтений столбца из Библиотеки Чарторыйских.

${ }_{45}$ Ссылка на альбом: Briquet $C h$. $M$. Les filigranes, dictionnaire historique des marques de papier dès leur apparition vers 1282 jusqu'en 1600. 4 vol. Genève, 1907. 


\section{Основной текст:}

(c. 1) Троице $\mathrm{e}^{46}$ пресущественая и пребожественая и преблагая правевьрующим в Тя, истинным крестьяном дателю премудрости, преневьдомый и пресвђтлый и крайний верх. Направи нас на истинну Твою и настави нас на повельнья Твоя, да возглаголем о людех Твоих по воле Твоей. Сего убо Бога нашего в Троицы славимаго милостию и хотьньем удержахом скипетр Росийского царствия. Мы, великий господарь, царь и великий княз Иван Васильевич всеа Русии самодержец владимерский, московский, ноугородцкий, царь казанский, царь астороханский, господарь псковский и великий княз смоленский, тверский, югорский, пермский, [вя]тцкий ${ }^{47}$, болгарский и иных господарь и великий княз Новагорода Низовские земли, черниговский, резанский, п[оло]цкий ${ }^{48}$, ростовский, ярославский, белоозерский, у[до]рский ${ }^{49}$, обдорский, кондинъский и всеа Сибирские земли и Сњверные страны повелитель и господарь отчинный земли Лифлянские и иных многих земель господарь самодержец.

Дражайшего и любезнъйшего брата нашего Максимилияна Втораго, Божиею милостию избраннаго цесаря римского всегда брибавителя ${ }^{50}$ неметцкого, угорского, чешского, долматцкого, кроатцкого, шлявонъского и иных, короля и арцыкнязя аустрийского, князя боргунского, // (с. 2) брабанского, стырского, каратынского, корниолского и иных, марграфа муравского, князя луцеборского Вышние и Нижние земли шлейского, вертемборского, князя швебского, грабя аушпорского, тиролского, фаретцкого, кибурского и горетцкого, ланкграбя алситцкого, монархи Римского царствия, бургунского, Вышние и Нижние земли люсатцкого, господаря мархинъского, склявонского и иных. Послом его Яну Кобендзль рыцерю с Просек, думцу и честному дворянину цесареву вьрному Даниелу Принцу.

По сему нашему писаню извещене даем боярином и дворетцким московским, и намъстником тферским Микитою Романовичем Юрьева, да дворянином Ближние думы и намъстником новоторжьским Офонасем Федоровичем Ногова, да дияки Ондрђем, да Василем Яковлевыми детми Щелкалова, да Иваном Дорофђевым. // (с. 3)

Бога в Троицы славимаго милостию великий господарь царь и великий княз Иван Васильевич всеа Русии, царь казанский, царь астороханский и многих земель царь и великий княз и многих земель господарь вам, послом брата своего дражайшего и любезнъйшего Максимилияна Фтораго, Божиею милостию избранного цесаря римского, угорского, чешьского, долматцкого и иных Яну Кобендзль, да Даниелу Принцу вельл говорити: говорили есте нам от брата нашего в посолстве, что приказал к нам с вами брат нашь цесар Максимелиян, чтоб вы нам известили, что до съх мъст его цесарево величество великие посольства до нашего величества не присылываны, потому что датцкому королю с свђйским королем для Ливонские земли промеж ими мир не пришел. И того для к нам послов отпустити не мог. Потом с неметцкими радами думал, как бы к нам послов послати, и то посолство тогды брат нашь цесарь поотложил, для того, что короля полского славные памяти Жигимонта Августа не стало, на которого мЂсто

\footnotetext{
46 1-я буква иницииал.

${ }^{47}$ Буквы утрачены; П: вятцкий.

${ }^{48}$ Повреждено; П: полотцкий.

${ }^{49}$ Буквы утрачень; П: удорский.

${ }^{50}$ Так в рукописи; П: прибавителя.
} 
корол францовской был обран. А после того, не долго живучи, королевство покинув, проч пођхал. И того для всего брат нашь цесар Максимилиян таково великого и славного посолства против своей воли до съх мъст до нас отправити не мог. А так брат нашь цесар для братства и приятельства прямого, которое с нами имъет, то все хочет вборзе учинити, чтоб нашему царскому величеству от подданных наших и от всђх господарей сторонних великая слава и честь была к нам.

А брат наш Максимилиян цесарь болши того ничего не хочет имъти милее и любимее, что от нас всегды писанье и посолства. А то ему было велми досадно, что прошлого времени гонца нашего Никона Ушакова, которого есмя к нему, к брату своему Максимили // (с. 4)яну цесарю послали с Павлусом с Магнусом да з Григорьем Вестьфолом ${ }^{51}$ вмЂсте свђйской вельл поимати и засадити. И брат нашь цесарь Максимилиян от свђйского болши нашего имъет кривду. И того ж часу до свђйского писал, чтоб того Никона к нам отпустил. И начаетца, что свђйской того нашего гонца Никона к нам отпустил. А тое наше писание, которое мы с тъм Никоном к нему, брату своему, послали через Григоря Вестьфола, до него дошло в прошлом году июля 26-го дня, и с тођ грамоты брат нашь Максилиян ${ }^{52}$ цесарь $^{53}$ нашь братственой и ласковой умысл и склонность гораздо ${ }^{54}$ выразумъл, что мы к нему и к его дътем любимым и ко всему славному народу ракузскому дьлаем.

И того для брат нашь цесар Мак//(с. 5)симилиян, кажючи умысл свой любителской и приятелской, с великою охотою того жадаючи хотьл, чтоб великое и славное посолство вдруг до нас отпустити и наше желание исполнити. Да толко для предреченных притчей то дъло сстатис не могло. И того для брат нашь умыслил, что наперед хочет о том о всем с своими радами и со всьми князи на нынешнем зборе достаточне о всем подлинно подумати и приговорити, // (с. 6) а после того тому начало учинити, чтоб нашему величеству болшую славу и честь учинити. И того ся начаете, что то дђло в коротком времени здђлаетца. И того для брат нашь Максимилиян цесар тьми времены до нас вас наперед отпустил, чтоб вы нашему величеству особливе приятелство и братъство его брата нашего Максимилияново цесарево сказали, которое върно и праведливо розсказуете, что брат нашь о нъкоторых дълех, которые в нашем писане именуютца. И он ть дъла братцки прияет и любит, и нам бы его цесарскому величеству в том особливе вьрити, что склонность свою брат нашь к нам имъет. И нам бы ныне лутчее выразумъти, // (с. 7) а что мы в писание своем не в одном, но и во многих грамотах к нему, брату своему, писали, а особливе надостоли о нынешнем дъле о Королевстве Полском братцким пособием вспоминали и сердечно того жедаем, чтоб его, брата нашего, любимой сын архикняз Гернист был на Королевстве Полском и на Великом княжствђ Литовском и к Паном есмя обоих панств ${ }^{55}$ напоминали, чтоб они то дњло потому учинили, и то им подлинно обецали, что мы тогды с ним, с королем доброе сусьдство и приятельство держати хотим. И с ним заодин стояти против всьх недругов. // (с. 8)

И тому всему мы всякое добро сполна свђтло учинили, что стол добро и приятелно и сердечно к брату своему всякую любов имњти хотим. И брат наш такую нашу любов

\footnotetext{
${ }^{51}$ Буква л из др. буквы (н).

${ }^{52}$ Так в рукописи.

${ }_{53}$ Буквы рь смазаньл.

${ }^{54}$ Буквы зд частично в чернильном пятне.

${ }_{55}^{5}$ Буквы пан по затертому рад.
} 
с радостью выразумъл, что вы нашему царьскому величеству того и выговорити не можете, то нам праведливо сказываете и утвердити можете. А брат наш цесарское величество и с сыном своим любителным за тую вђрность и за нашу великую любов против того и с убытком своих господарств и здоровъм и кровю своею задълывати хочет, толко б на него и на его сына на Герниста какие причины не было. И он за то за все покажет любов свою прителскую ${ }^{56}$ и братцкую. И нъкоторым своим великим приятелем наше приятелство сказал. И они всь того жадают, чтоб нам з братом нашим быти в приятелстве. И ныне величество наше от тьх часов славят. А брат наш цесар безпрестани того ищет всегды, чтоб ему нам ласка своя свђтла и знатна передо всъм свђтом показати.

А наше величество о том гораздо въдаем, что то королевство топере есть без господаря и многие хотят арцыкняжати Гернаста и многие были на том // (с. 9) произволили, как были на своем совђте в Стежице и х тому было пришло, что его на королевство взяти хотъли, толко б люди упрямые своим упрямством не испортили. А коли то не ссталос, а через тот час мног не столко Панов полских и от литовских Панов через писане и через послы свои без обманки върно въсть дали, что иного никого себъ за короля взяти не хотят, толко арцыкняжа Герниста с великою просбою, чтоб он брат наш от того дъла не отставал, чтоб вмђсте с ним с великим печалованем то докончал, коли они того хотят, что корол их выбраный до них опят не пришел, и они б себъ иного короля обрали.

А как есте ьхали через Литву и одва есте в Литвђ трех панов видели, а ть всь пођхали в Полшу на совђт, о чем брат наш, как вы от него и пођхали, не въдал. И на том уже договорилос, чтоб арцыкняжа Гернист был на Полском королевствђ и нам бы послати до Панов полских и литовских, чтоб арцыкняжа Герниста мимо иных всьх за короля себъ обрали, сказываючи им о покое и о правдивом приятелском сусьдстве и соединене против // (c. 10) всьх недругов. И толко мы им так напишем, и с того значной и великой пожиток брату нашему и сыну его арцыкняже Гернисту будет, также и нам новой пожиток и всякое дъло к доброму концу пришло, чтоб то безо всякие хитрости доступити. А тъм бы нам всњм сопча всъх своих недрузей станы порушити не токмо вашего головного неприятеля турского салтана или иных брата нашего и наших недрузей, а себъ бы нам великой пожиток учинити, да к брату нашему цъсарскому величесту недавно прошлыми часы изо многих мъст, а больши от ливонских людей та ръч дошла, что мы прошлого году генваря мъсеца до повъту круг города Колывани, с великими людми въъхав, все выпустошил и выжег и иные городы, Пернов, силою взял, а иные облег. И брат наш тому // (с. 11) велми дивитца также брата нашего и сына его Герниста и Панов полских и литовских то дъло велми закручинило и нам бы людей своих от рубежа ливонского отвести, а с королевством Полским и с Великим княжством Литовским и с Ливонскою землею в добром сусьдстве и в покое жити.

А не толко тьх земел облаадателем, и иным бы всьм землям, то явно нам показати, чтоб мы иного ничего не мыслили, только б то, чтоб арцыкняжа Гернист был на Коруне Полской. А будет не мочно словом, ино б и силою, или как ни буди мочно нам учинити, чтоб их закручинити. А ливонских бы нам людей отставити для того, что ливонские люди брата нашего цъсаревы люди и его землю Немецкую по всяк час над собою их имъют. А мы за их грубость Юрьев взяли, а топере для ж того у нас недружба с свђйским королем о городе о Колывани. И нам бы з братом своим с цесарем жити

\footnotetext{
${ }^{56}$ Так в рукописи.
} 
потому ж, как наши предкове сь его прежними жили. Брат наш Максимилиян цђсар с нами болши того в прямом приятелствђ хочет быти и Коруна Полская и Княжство Литовское и Ливонская // (с. 12) земля, которая брата нашего к Максимилиянове цъсареве земль прилегла. А которая меж нами недружба с королем с свђйским и в тђ трудности свђйской неподълно вступаетца. И как будет выбран на Королевство Полское и на Великое княжство Литовское брата нашего Максимилиянов цесарев сын Гернист и тогды будет вечный покой и приятелство и сусьдство и соединене против всъх недругов. И толко брата нашего сын княжата Гернист на Коруне Полской и на Великом княжствђ Литовском будет, и тогды брат наш Максимилиян цъсарь не оманкою с нами свое властное господарство и княжство и своих детей в вечном покое утвердит хочет для того, коли брата нашего Максимилиянов цъсарев сын Гернист с нами, как с силным и с вЂрным братом ближним сусьдом станет и он с нами еж час против наших недругов, гдњ будет надобет, всегды будет готов. // (с. 13)

$\mathrm{A}^{57}$ коли мы с порубежными крестьяны в таком милом покое жити будем и против поганых и иных невьрных можем ся оборонити и славу свою добрую обдержати, которая нам от Бога дана, как отец нашь блаженные памяти великий господарь Василей учинил крестное целоване с королем полским с великими их пожитки и после того много княжств, которые и топере мы под свою руку взяли. А толко брата нашего Максимилиянову цесареву сыну княжати Гернисту Королевство Полское Бог в руки даст за нашею помочю и за помочю брата нашего Максимилияна цесаря и против недруга мы поидем своими людми с своей стороны, а брата нашего Максимилиянов цесарев сын княжата ${ }^{58}$ Гернист с полские и с подолские границы с своими людми, а брат нашь Максимилиян цесар и з Угорские, и з Свединские земли с Ко // (с. 14)рватцкие земли с своими людми, а корол ишпанский брата нашего Максимилиянов цесарев любителный сын с Папою с римским, и с ыными господари крестьянскими на головного недруга и невърного окрутника на море и на земль с великою силою прити. И у него бы то отнят за милостю Господа Бога в кротком чесу, что он через колко сот льт царствовал и воевал многих крестьянских // (с. 15) господарей и с великим соромоценем и спустошеньем. А в том святом соединене мы можем начаятис великие себъ чести и славы и от Господа Бога помочи, чтоб нам тъх невЊрных людей выгнати за Арапы и до Ази. Чтоб произволенем брата нашего Максимилияна цесаря и Папы римского, и короля ишпанского, и брата нашего Максилиянова ${ }^{59}$ цесарева сына княжати Герниста и выбраных римских княжат все царство Греческое на всход солнца к нам пришло. И от брата б нашего Максимилияна цесаря и от Папы римского и ото всего // (с. 16) хрестьянства нам и дътем нашим любителным честно и славно было. А после того брату нашему Максимилияну цесарю к радости и всему крестьянству пришло и хрестьянство б все с радостию и с утъхою и с великим моленем того ся дождало, чтоб безбожная Магаметева въра была выкоренена, а крестьянская въра высилась. А мы б и иные господари крестьянские того с прямым сердцем могли начаятис, которые крестьяне через немалой час великую нужу магметцкую терпъли и ныне терпят и вперед своими повсяденными просбами у Господа Бога просят о великом свобожене от поганых. Того для вы нам с великою

${ }^{57}$ С этого места и далее на протяжении всего сстава другим, более жирным, почерком, далее снова прежний почерк.

${ }_{58} 2-я$ а из е.

${ }^{59}$ Так в рукописи. 
покорностью напоминаете именем брата нашего Максимилияна цесаря и велми того просите, чтоб мы з братом своим с Максилияном ${ }^{60}$ цесарем и с сыном его княжатем Гернистом великим разумом своим обмышливали и осматривали.

А брат нашь, Максими // (с. 17)лиян цесар, так приятельскии и братскии учинил, как брат нашь к нам велику надежю имъет, чтоб мы просбу и жедане брата своего Максимилияна цесаря пред собе взяли, что преж сего, пред сњми часы и $з$ ластные своей охоты и ласковости и любви против брата нашего Максимилияна цесаря славно и знакомито учинити, к людем полским отписати и их напоминати о брата нашего Максимилиянове цесареве сыне о Гернисте, чтоб тъм всъм, которые ся о том королевстве старают, отговаривали, а брата б нашего Максимилиянова цесарева сына за короля обрали и взяли и в том доброе сусьдъство и во веки покой и братцкое соединене учинити и прямые помочи против всьх недругов. А к брату бы нам своему Максимилияну цесарю и ко Святой Посполитой Рњше Римской от своего воинства дђла против Ливонские земли // (c. 18) престати, которая под началом была к Посполитой РЊше Римской и нынеча есть. А у брата нашого Максимилияна цесаря и у всеђ Рђши и у порубежных своих всегды помочи жедают и просят, и Рњша была произволила и хотьли были пособ учинити, и брат нашь Максимилиян цесар для тођ приятелские згоды и братцкие надежи с нами им на то не дозволил. А им въчный покой отдав на жеданнаго сусьдства обецовал учинити и своим гетманом в Ливонской земль приказал, чтоб перед нами гораздо справовалис и никому ничего неприятелского не учинили и от нашего бы пресветльй // (с. 19)шества вам ъхати з грамотами не мешкаючи до Полские и до Литовские земли. И ть бы грамоты всђм паном, как вмЂсте будут отдати, чтоб нам к брату нашему Максимилияну цесарю, чего издавна хотим и жадаем, как бы мочно вборзе не мешаючи счастливо и радостно с пожитком добрым всякое добро имьти ${ }^{61}$.

И мы посолство ваше выслушали и на то посолство извещение, что есте нам от брата // (с. 20) нашего от Максимилияна цесаря на посолстве говорили, что брат наш дражайший Максимилиян цесар с вами к нам приказывал, чтоб вам нам известити, что до сђх мњст брата нашего дражайшего великое посолство до нас не прислано для того, что свђйскому королю $з$ датцким королем в мир не пришло для Ливонские земли. А короля полского славные памяти Жигимонта Августа не стало, а ныне брат нашь для бра//(с. 21)тцства и приятелства прямово все хочет вборзе учинити, чтоб нашему царьскому величеству ото всьх господарей сторонних великая слава и честь была. А брат наш дражайши болши ничего не хочет имьти милее и любимее, чтоб меж нас с ним, 3 братом нашим $з$ дражайшим, всегды было писане и посолство о любви. И то брат нашь дражайши и любителный хочет себъ и нам обоим нашим господарством прибытъка, что приятелство все вборзе хочет учинити. И брат бы нашь своих великих послов со всњм с полным наказом до нас прислал, чтоб меж нами болшое дъло утвердилос, что всему крестьянству к покою.

A то брат нашь ${ }^{62}$ дражайший дњлает братцкую любов, что желает и любити хочет с нами посолства и зсылки и соединеня. А мы потому ж з братом своим дражайшим с Максимилияном цесарем хотим ссылки о братцкой любви и о соединение, // (с. 22) а что

\footnotetext{
${ }^{60}$ Так в рукописи.

${ }^{61}$ Далее отступ.

${ }^{62}$ Буква н из ш.
} 
есте говорили нам от брата нашего дражайшего от Макъсимилияна цесаря, что гонца нашего Никона Ушакова в поимане держит свђйской корол, а хочет к нам ${ }^{63}$ по присылке Макъсимилияна цесаря Никона отпустити и то свђйского перед нами и перед нашим дражайшим братом Максимилияном цесарем неисправедливост, что такому дълу чинит помЂшку, что з братом нашим начинаетца о братцкой любви, что всему хрестьянству х прибытку. А свђйской корол, забыв докончане с ноугородцкими намъстники, перед нами во мъногих не исправяс, нам укоризны великие и слова ${ }^{64}$ непригожие к нашему царьскому величеству в своих грамотах пишет, укоряючи наше царьское имя, а вступаяс в нашу отчину в Вифлянскую землю, чего никоторому господарю терпьти невозможно. Да мы терпим свђйскому, что меж нас з братом нашим Максимилияном цесарем ссылка учинилас о братцкой любви и нам бы изявити // (с. 23) брату своему дрожайшему Максимилияну цъсарю свђйского неправду и укоризна перед братом нашим Макъсимилияном цъсарем было бы то явно.

А что есте говорили нам от брата нашего Максимилияна цђсаря, что мы к брату своему многижда писали, а в посльдней своей грамоте, которая была послана с Никоном с Ушаковым писали к брату своему Максимилияну цъсарю, хотя того, чтоб на Коруне Полской и на Великом княжствђ Литовском был брата нашего дражайшего сын Гернист княз аустрђйский. А ныне то господарство порозже, и нам бы тьм промышляти и брату нашему дражайшему Максимилияну любов своя показати, чтоб брата нашего сын Гернист княз аустрђйский был королем на Коруне Полской, и быт бы нам з братом нашим Максимилияном цесарем и $3{ }^{00-}$ сыном его ${ }^{-65}$ Гернистом в докончанье и в соединене и на всякого недруга быт нам заодин, да и Ливонская земля была бы х Коруне Полской и к Великому княж // (с. 24)ству Литовскому, которая прилегла к цесареве земль. И мы, как преж сего хотьли есмя, так и ныне хотим з братом своим 3 дражайшим с Максимилияном цъсарем братства и докончаня и соединеня на всякого недруга быти заодин и того ныне хотим, как преж сего для любителного братства и соединеня писали есмя к брату своему к Максимилияну цъсарю, что присылали к нам Паны Коруны Полские и Великого княжства Литовского до Рады присяглого дияка Михаила Голобурду, чтоб нам быти у них на господарстве или сына своего дати им на господарьство. И мы к ним приказали с Михаилом з Голобурдою, что мы у них господарем быти хотим и сына своего на господарьство дати хотим. А будет за которым случаем быть у них нам господарем невмъстно, и они б никого иного себъ за господаря не обирали, кромъ сына цъсарева Герниста. А нам то будет любо таково ж, что будет на Коруне Пол // (с. 25) ской сын цесарев Гернист, что и сын наш царевич Федор будет на Коруне Полской и на Великом княжствђ Литовском. А будет похотят литовские люди опрочь Коруны Полские на Великое княжство Литовское нашего над собою господарьства и мы им на одно на Великое княжство Литовское быти у них хотим, то есмя к Радом с Михайлом Галабурдою писали. А ныне наше хотъне то, чтоб брата нашего дражайшего сын Гернист, княз аустрђйский, был на Коруне Полской, а Литовское б Великое княжство и с Киевом, и что к нему городы были к нашему господарьству к Московскому. А Ливонская земля изначала была наша вотчина и нашим прародителем ливонские нъмцы дан давали, да

\footnotetext{
${ }^{63}$ Буквы к н по затертому.

${ }^{64}$ Буквы лова по затертому или смазаны.

${ }^{65}$ Отрывок по затертому.
} 
забыв правды, от нас отступили, и дани давати не почали, и многие грубости и вины и неисъправленья при нашем господарстве перед нами показали. И над нашими людми многие насилства и обиды и грабежи // (с. 26) чинили, и над Ливонскою землею потому от нас и зсталос за их неправды. И Ливонской земль и Курской ${ }^{66}$ всей быт к нашему господарьству. Да и для того Ливонской земль быт за нами, что есмя взяли и учинили при себъ голъдовника своего короля Арцы-Магнуса на своей вотчине на Вифлянъской земль. И правду свою к нам корол Арцы-Магнус учинил, целовал нам крест, как ему в нашем жаловане быти у нас на Вифлянской земль, а которым городом болшим быти за нами, которые себъ возмем и тъм городом быти за нами, да на том и хрестным целованем затвержено. И нам и потому через правду никому иному Лифлянъской земли поступитис невозможно. // (с. 27) А брат бы наш дражайший Максимилиян цысар для нашие к себъ любви и братства, и соединеня в Ливонскую землю не вступался, тьм бы нам любов свою показал. А что нам с свђйским недружба о городе о Колывани, и нам бы людей своих от рубежа ливонского отвести, а с Королевством Полским и с Великим княжством Литовским и с Ливонскою землею в добром судстве ${ }^{67}$ и в покое жити. И мы Ливонской земле своей вотчины з Божиею помочю доставаем и вперед хотим искати, которые вступилис в Ливонскую землю не по правде корол датцкой и свђской и поимали многие городы в Ливонской земль, как мы Ливонскую землю опустошили и розарили за их неправды и за непослушание. А покамъста мы своей вотчины не искали и на Ливонскую землю гнђ//(с. 28)ву своего не положили и в Ливонскую землю нихто не вступался. И брат бы нашь дражайший в Ливонскую землю не вступался, и с нами которое дъло болшое починаетца, что всему крестьянству к прибытку и к обороне, не рушил ${ }^{68}$.

А что есте нам говорили от брата нашего Максимилияна цесаря, чтоб нам послати до Панов полских и литовских, чтоб сына его Герниста князя мимо иных всьх обрали себъ за короля, сказываючи им о покое и о правдивом нашем приятелском сусьдстве и соединене против всьх недругов, и толко мы к ним так прикажем и с того знатной и великой пожиток брату нашему и сыну его арцыкняже Гернисту будет, также нам новой пожиток и всякое доброе дњло к добру будет. И мы ныне по брата своего дражайшего присылке, по вашему посолству, пошлем грамоты х Коруне Полской и к Великому княжству Литовскому для братцкие любви, напоминаючи Панов полских, чтоб оне обрали себъ за короля брата нашего дражайшего сына Герниста князя на Королевство Полское а Великого княжства Литовского Панов, // (с. 29) напоминаючи, чтоб Великое княжство Литовское было под нашим господарством и господарству нашему к Московскому.

А ныне к нам в Можаеск, при вашем, брата нашего, посльх приђзде приђхал нашь посланник из Литвы, и многие Паны к нам приказывали полские и литовские, просечи нас, чтоб мы к ним послали своих посланников, а они хотят над собою нашего господарьства на Коруне // (с. 30) Полской и на Великом княжьствђ Литовском.

А иные обрати хотят себъ за господаря по присылке турского салтана воеводу семиградцкого. И мы для братцкие любви брата своего дражайшего Максимилияна цесаря хотим того, чтоб взяли себъ за короля на Коруну Полскую брата нашего //
${ }_{66}^{6}$ Так в рукописи.
${ }^{67}$ Так в рукописи.
${ }^{68}$ В П далее читается: а нам бы тем свою любителную братцкую приятелную любовь показал. 
(c. 31$)$ дражайшего сына Герниста, князя аустрђйского, а о том бы нам з братом нашим дражайшим Максимилияном цесарем тьм промышляти сопча, чтоб семиградцкого воеводы по присылке турского салтана на то господарьство на Коруну Полскую и на Великое княжство Литовское Панове рада не имали, чтоб им самим Коруне Полской и Великому княжству Литовскому и всъм крестьянским господарем к убытку не было, а бесерменским господарем нашим к повышеню.

А мы о том // (с. 32) з братом нашим дражайшим с Максимилияном цесарем учнем сопча промышляти, чтоб на Коруне Полской и на Великом княжстве Литовском нашим осмотренем меж нас в братцкой любви мимо нас и брата нашего дражайшего сына не был нихто.

А мы, будучи з братом своим дражайшим с Максимилияном цесарем в докончане и в братцкой любви и в соединене, и сыном его з Гернистом, как будет на Королевстве Полском, учнем стояти на всякого недруга заодин.

А мы брату своему дражайшему хотим любов свою казати и промышляти з братом своим 3 дражайшим с Максимилияном цесарем сопча, чтоб брата нашего дражайшего и любителного сын его Герни//(с. 33)ст, аустрьйский княз был на Коруне Полской, а Великое б княжство Литовское было за нами к Московскому господарьству, и Лифлянская земля! А утвердяся б нам з братом своим з дражайшим и любезньйшим с Максимилияном цЊсарем и с сыном сь его з Гернистом, королем полским, утвердив докончане о въчном соединене, и на дъти. И стояти нам обще всђми господарьствы с Папою римским и с королем ишпанским и со всьми господари поморскими на всякого недруга заодин. А датцкой б и свђйской потому ж с нами и з братом нашим с Макъсимилияном цҺсарем были в докончанье по прежним обычаем. А в чем свђйской перед нами не исправился и брат бы нашь дражайший Макъсимилиян цесар свђйскому исправитися перед нами вельл и докончане бы себъ свЂйской учинил с нашею вотчиною с Великим Новым // (c. 34) городом с нашими намъсники по прежним обычаем, как отец ${ }^{69}$ его Хрестерн был в докончане с Великим Новым городомь и как будет пригож, чтоб всякой был с нами и з братом нашим дражайшим с Максимилияном цесарем в ${ }^{70}$ дончане ${ }^{71}$ на всяких $^{72}$ наших ${ }^{73}$ недругов ${ }^{74}$ зао//(с. 35)однь ${ }^{75}$.

А что есте говорили говорили с нашими бояры, что вам ознаменили от нас о Ливонской земль, и брат нашь Максимилиян вельл вам о том толко помян[у]ти ${ }^{76}$. А много про Ливонскую землю говорити вам не велено. Толко бы мы Ливонские земли до тьх мъст воевати не вельли, покамъста болшие посл[ы] $]^{77}$ брата нашего цесаревы у нас будут. А ть дъла всь, которые есте нам на посолстве говорили, вельл вам брат нашь нам обявити, чтоб нам про ть, про всђ дњла было в въдоме. А заключити вам тьх дъл брат нашь не вельл. А для докончаня о тьх о всьх дњлех брат нашь пришлет к нам своих

${ }^{69}$ Концевая ъ из др. буквы.

${ }^{70}$ Виисана в строке.

${ }^{71}$ Так в рукописи.

${ }_{72}$ Буква х из м.

${ }_{73}^{75}$ Буква х из м.

${ }^{74}$ Буква в из м.

${ }^{75}$ С начала сстава новым почерком.

${ }^{76}$ П:

${ }^{77} \Pi:$ так. 
великих послов удьлных князей, каковы задолго льт не бывали. И коли меж нас з братом нашим с Максимилияном цесарем такое дъло всчинаетца о соединене и о веч//(с. 36)ном братъстве и о дружбе и то б дъло меж нас з братом нашим было крђпко и неподвижно.

А мы, ком $[\mathrm{y}]^{78}$ слово свое молвим о братъстве и о любви, и то живет крђпко и неподвижно. А иноко слово наше не живет, не так бы было, как преж того корол Лодвик Владиславов сын Угорской, сослався с цесарем и со многими неметцкими господари, захотъл стояти против турского. И как на него пришел турской, и цесар и неметцкие господари ему не пособили, и помочи не учинили, его выдали, и турские люди его побили, да и самого убили. И которые господари з братом нашим с Максимилияном цесарем в докончание Папа римской, и корол ишпанской, и корол датцкой, и архикнязи, и комиты, и всякие началники, и тъ б всь господари з брата нашего с Максимилияновым цесаревыми с великими послы прислали к нам своих послов, и утвердилис всњ с нами в докончание, как пригож на всяких недругов стояти всђм им с нами заодин. А мы на их недрузей учнем стояти заодин.

А что есте говорили, чтоб вам самим от нас дати грамоты х полским и к литовским Паном радам, ${ }^{00-}$ и вам грамот $\kappa^{79}$ своей брате х Паном вести непригож. В нашем обычае $^{80} \mathrm{To}^{-81}$ безчестно, что послом з грамотами ьздити. А велим послати // (с. 37) ть грамоты в Литву х Паном радам из Моленска ${ }^{82}$ 00-с своим посланником-83 часа того, а в грамотах пишем х Коруне Полской Паном, чтоб Коруны Полской Паны взяли себъ на Коруну Полскую брата нашего дражайшего сына Герниста архикнязя. А нам брат нашь Максимилиян цъсарь и сын его Гернист будут с нами в докончане и в соединенье на всякого недруга заодин. А к Великому княжству Паном пишем, чтоб они под нашим господарством к Московскому господарству были. А мы з братом нашим с Максимилияном цесарем и с сыном сь его з Гернистом учнем быти в доконъчанье на всякого недруга заодин. А будет Великое княжство не похочет быти под нашим господарствам опрочъ Коруны Полские, и они б были с Коруною Полскою общи и взяли себъ на тъ на обе земли брата нашего Максимили//(с. 38)янова сына Герниста, толко бы в рубежъх о нъкоторых дълех договор учинили цъсаревы послы у нас будучи. А не похотят Коруны Полские и Великого княжства Литовского Паны рады нас и сына твоего Герниста князя на Коруне Полской и на Великом княжстве Литовском господарем, и нам з братом своим с Максимилияном цесарем над Коруною Полскою и над Великим княжством обще промышляти и в неволю приводити.

А что есте нам говорили // (с. 39) от брата нашего Максимилияна цесаря, чтоб нам брату своему приказати, что будет нам надобет из его господарства, что нам пригодитца, и бра[т] $]^{84}$ нашь для любви к нам пришлет. И брат бы нашь для любви прислал к нам церковных и городовых и полатных мастеров, да мастеров, которые досчатые доспьхи

\footnotetext{
${ }^{78} \Pi: \operatorname{ma\kappa }$.

${ }^{79}$ В рукописи далее буква, сходная с в (возможно, не дописана ъ).

${ }^{80}$ Буква а из е.

${ }^{81} B$ П данный фрагмент читается: и что в грамотах писано и нам бы то вам изъявити, чтоб господарю вашему было то явно, 一 и вам грамот к Паном к своей брате самим [слово вписано над строкой] вести непригож, то в нашем обычае.

${ }^{82}$ Так в рукописи.

${ }^{83}$ П: нет.

${ }^{84} \Pi: \operatorname{ma\kappa }$.
} 
делают, да бархатов с петлями двое морхих, да латы неметцькие с рукавы, которые б нам пригодилися добрые, да пищалей коротких конских по полуторе пяди пищал, которые б были стенисты и далеко б убивали и стрелять бы из них было безстрашно. А что будет брату нашему надобет из нашего господарства и мы против брату своему для любви пришлем.

А толко Коруны Полские и Великого княжства Литовского Рады нашего господарства над собою и брата нашего Максимилияна цесаря и сына его Герниста князя не похотят, и нам бы з братом своим с Максимилияном цесарем промышляти и того себъ господарства доступати. И вам, послом, бояре наши говорили от господаря вашего, о том наказ ест ли? И вы говорили, что вам о том от брата нашего наказу нът. А будут к нам о тьх о всђх дълех от брата нашего великие послы, и брат бы нашь Максимилиян цесар послов своих великих, наказав им о всем подлинно, слал к нам ранея, чтоб нашему общему дълу порухи не было.

\section{CTEMma}

«Ответ» Ивана IV Иоганну Кобенцлю и Даниилу Принцу

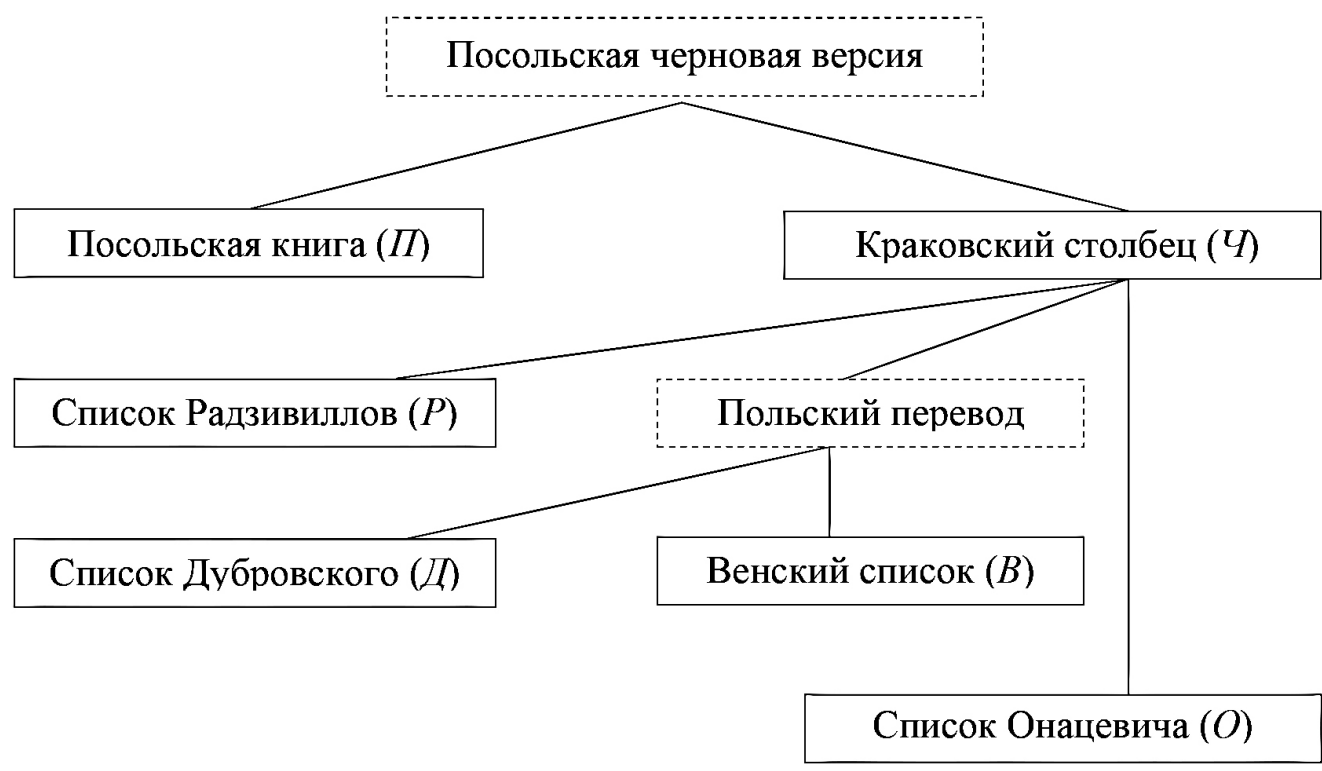

Информация о статье

Исследование выполнено при поддержке Российского научного фонда, проект № 16-18-10091 «Дипломатическая переписка Ивана Грозного: Исследование и публикация посланий (1533-1584 гг.)».

Авторы: Бачинский, Алексей Александрович - кандидат филологических наук, Москва, Россия, OrcID 0000-0001-6291-6864, e-mail: bachinskiy2013@gmail.com;

Ерусалимский, Константин Юрьевич - доктор исторических наук, доцент, профессор, Российский государственный гуманитарный университет, Москва, Россия, ScopusID 57203189594, e-mail: kerusalimski@mail.ru;

Козляков, Вячеслав Николаевич — доктор исторических наук, профессор, Рязанский государственный университет имени С.А. Есенина, Рязань, Россия, OrcID 0000-0003-2840-9767, ScopusID 55485664700, SPIN-код 3031-0269, AuthorID 346771, e-mail: v.kozliakov@365.rsu.edu.ru; 
Шварц, Искра - доктор философских наук, профессор, Институт восточноевропейской истории Венского университета, Вена, Австрия, ScopusID 57203182975, e-mail: iskra.schwarcz@univie.ac.at Заголовок: Проект раздела Речи Посполитой между Россией и Священной Римской империей: Краковский столбец начала 1576 года

Резюме: Имперское посольство Иоганна Кобенцля и Даниила Принца в декабре 1575 - январе 1576 г. обсуждало с царем Иваном IV и его представителями последствия победы императора Максимилиана II Габсбурга на выборах короля в Великом княжестве Литовском и Короне Польской. В Библиотеке Чарторыйских в Кракове хранится ответ царя - столбец (Perg. 2822/IX), переданный послам для императора, однако получивший известность среди современников в Короне и Литве. В статье изучена рукописная традиция текста столбца. Отличия между списками посольской книги, столбца, литовской русской версией, польским и латинскими переводами позволяют высказать предположение о вовлеченности самого столбца и его списков в политическую борьбу 1576 г.

Ключевые слова: Иван Грозный, Максимилиан II Габсбург, российская дипломатия, Речь Посполитая Литература, использованная в статье:

Бойщов, Михаил Анатольевич. Различные взгляды на посольство Ивана IV к императору Максимилиану II в 1576 г. // Бойцов М. А., Виноградов А. Ю., Воскобойников О. С. и др. Средневековая Европа: Восток и Запад. Москва: Издательский дом НИУ ВШЭ, 2015. С. 327-364.

Дубровский, Игорь Владимирович. Исследования о дипломатической переписке Ивана Грозного // Русский сборник: исследования по истории России. XXIV: Московия в свидетельствах иноземцев / Отв. сост. тома И. В. Дубровский. Москва: Модест Колеров, 2018. С. 30-389.

Ерусалимский, Константин Юрьевич; Швари, Искра. Миссия Ждана Квашнина в Священной Римской империи: К истории российско-имперских отношений XVI века // Studia Slavica et Balcanica Petropolitana. 2018. № 1 (23). C. 71-104.

Лурье, Яков Соломонович. Новые данные о посольстве Сугорского и Арцыбашева в 1576 г. // Исторические записки. 1948. Москва: Акад. наук СССР. № 27. С. 291-300.

Филюшкин, Александр Ильич. Изобретая первую войну России и Европы: Балтийские войны второй половины XVI в. глазами современников и потомков. Санкт-Петербург: Дмитрий Буланин, 2013. 881 c. Флоря, Борис Николаевич. Русско-польские отношения и политическое развитие Восточной Европы во второй половине XVI - нач. XVII в. Москва: Наука, 1978. 303 с.

Augustynowicz, Christoph. Die Kandidaten und Interessen des Hauses Habsburg in Polen-Litauen während des Zweiten Interregnums 1574-1576. Wien: WUV, Universitätsverlag, 2001. 205 s.

Donnert, Erich. Der livländische Ordensritterstaat und Rußland: Der Livländische Krieg und die baltische Frage in der europäischen Politik 1558-1583. Berlin: Rütten \& Loening, 1963. 320 s.

Dubas-Urwanowicz, Ewa. Koronne zjazdy szlacheckie w dwóch pierwszych bezkrólewiach po śmierci Zygmunta Augusta. Białystok: Uniwersytet w Bialymstoku, 1998. $382 \mathrm{s.}$

Ferenc, Marek. Mikołaj Radziwiłł «Rudy» (ok. 1515-1584): Działalność polityczna i wojskowa. Kraków: Historia Iagellonica, 2008. $672 \mathrm{~s}$.

Forstreuter, Kurt. Preussen und Russland von den Anfängen des Deutschen Ordens bis zu Peter dem Großen. Göttingen; Berlin; Frankfurt: Gottingen u. a.: Musterschmidt-Verl., 1955. (Göttinger Bausteine zur Geschichtswissenschaft. Vol. 23). $257 \mathrm{~s}$.

Kappeler, Andreas. Ivan Groznyj im Spiegel der ausländischen Druckschriften seiner Zeit. Ein Beitrag zur Geschichte des westlichen Russlandbildes. Bern: Herbert Lang. Frankfurt am Main: Peter Lang, 1972. (Geist und Werk der Zeiten. Arbeiten aus dem Historischen Seminar der Universität Zürich. No. 33). 298 s. Laucevičius, Edmundas. Popierius Lietuvoje XV-XVIII a. Atlasas. Vilnius: Mintis, 1967. 577 p.

Lulewicz, Henryk. Gniewów o unię ciąg dalszy: Stosunki polsko-litewskie w latach 1569-1588. Warszawa: Neriton - Instytut Historii Polskiej Akademii Nauk, 2002. 457 s.

Poe, Marshall. Foreign Desriptions of Muscovy: An Analytic Bibliography of Primary and Secondary Sources. Columus, Ohio: Slavica Publishers, 1995. P. 230 p.

Schellhaß, Karl. Zur Legation des Kardinals Morone (1576; Moskau, Bayern) // Quellen und Forschungen aus Italien. Archiven und Bibliotheken. Rom: Verlag von Loesher \& Co, 1910. № 13. S. 273-376.

Information about the article

The research is supported by the Russian Scientific Foundation, project No 16-18-10091.

Authors: Bachinskiy, Aleksey Aleksandrovich - PhD in philology, Moscow, Russia, OrcID 0000-00016291-6864, e-mail: bachinskiy2013@gmail.com; 
Yerusalimski, Konstantin - Doctor of historical sciences, Professor, Russian State University for the Humanities, Moscow, Russia, Scopus ID 57203189594, e-mail: kerusalimski@mail.ru;

Kozlyakov, Vyacheslav Nikolayevich - Doctor of historical sciences, Professor, Ryazan state universitu named by A. Yesenin, Ryazan, Russia, OrcID 0000-0003-2840-9767, ScopusID 55485664700, SPINкод 3031-0269, AuthorID 346771, e-mail: v.kozliakov@365.rsu.edu.ru;

Schwarcz, Iskra - PhD in history, Professor, Institute of Eastern European History, University of Vienna, Austria, ScopusID 57203182975, e-mail: iskra.schwarcz@univie.ac.at

Title: The Project of the partition of the Polish-Lithuanian Commonwealth between Russia and the Holy Roman Empire: The Cracow roll-message from 1576

Summary: The imperial embassy of Johann Kobentzl von Prosseg and Daniel Prinz von Buchau discussed with tsar Ivan IV and his representatives in December 1575 - January 1576 the consequences of Maximilian II Habsburg's election on the thrones of the Grand Duchy of Lithuania and the Polish Crown. There is the roll-message in Cracow Chartorysky Library (Perg. 2822/IX), which has been sent to the emperor with their legates. It became known among contemporaries in Poland and Lithuania. The authors of the article strive to analyze the manuscript tradition of the roll. The differences between its Moscow ambassadorial, Lithuanian Russian, Polish and Latin copies show that the roll took part in the political struggle of the period.

Keywords: Ivan the Terrible, Maximilian II Habsburg, Russian diplomacy, Polish-Lithuanian Commonwealth

\section{References:}

Augustynowicz, Christoph. Die Kandidaten und Interessen des Hauses Habsburg in Polen-Litauen während des Zweiten Interregnums 1574-1576 [Candidates and Interests of the Haus of Habsburgs in Poland and Lithuania during the Second Interregnum, 1574-1576]. Wien: Universitätsverlag Press, 2001. 205 p. (in German).

Boycov, Michail Anatolyevich. Razlichnye vzglyady na posol'stvo Ivana IV k imperatoru Maksimilianu II v 1576 g. [The Opinions on the Embassy of Ivan IV to the Emperor Maximilian II in 1576], in Srednevekovaya Evropa: Vostoki Zapad. Moscow, 2015. Pp. 327-364. (in Russian).

Donnert, Erich. Der livländische Ordensritterstaat und Rußland: Der Livländische Krieg und die baltische Frage in der europäischen Politik 1558-1583 [The Livonian State of the German Order and Russia: The Livonian War and the Baltic Question in European Politics, 1558-1583]. Berlin: Rütten und Loening Publ., 1963. 320 p. (in German).

Dubas-Urwanowicz, Ewa. Koronne zjazdy szlacheckie w dwóch pierwszych bezkrólewiach po śmierci Zygmunta Augusta [Conventions of the Polish gentry in the First and the Second Interregna after Sigismund II August Decease]. Białystok: Uniwersytet w Bialymstoku Publ., 1998. 382 p. (in Polish).

Dubrovskiy, Igor Vladimirovich. Issledovaniya o diplomaticheskoj perepiske Ivana Groznogo" [Studies on the Diplomatic Correspondence of Ivan the Terrible], in Russkiy sbornik: issledovaniya po istorii Rossii. XXIV: Moskoviya v svidetel'stvah inozemcev. Otv. sost. toma I. V. Dubrovskiy. Moscow: Modest Kolerov Publ., 2018. Pp. 30-389. (in Russian).

Erusalimskiy, Konstantin Yuryevuch; Schwarcz, Iskra. Missiya Zhdana Kvashnina v Svyashhennoy Rimskoy imperii: K istorii rossiysko-imperskih otnosheniy XVI veka" [The Mission of Zhdan Kvashnin in the Holy Roman Empire: On the History of Russian-Imperial Relations of the 16th Century], in Studia Slavica et Balcanica Petropolitana. 2018. № 1 (23). Pp. 71-104. (in Russian).

Ferenc, Marek. Mikołaj Radziwiłt „Rudy” (ok. 1515-1584): Działalność polityczna i wojskowa [Mikolay Radzivill „Rudy”, (ca. 1515-1584): Political and Military Activity]. Kraków: AiD Publ., 2008. 671 p. (in Polish).

Filyushkin, Aleksandr Ilyich. Izobretaya pervuyu vojnu Rossii i Evropy: Baltiyskie vojny vtoroy poloviny XVI v. glazami sovremennikov i potomkov [Inventing the First war between Russia and Europe: Baltic wars of the second half of the 16th century from the perspective of contemporaries and descendants]. Saint Peterburg: Dmitriy Bulanin Publ., 2013. 845 p. (in Russian).

Florya, Boris Nikolayevich. Russko-pol'skie otnosheniya i politicheskoe razvitie Vostochnoy Evropy vo vtoroy polovine XVI-nachale XVII v. [Russian-Polish relations and the political development of Eastern Europe in the second half of the 16th-early XVII century]. Moscow.: Nauka, 1978. 303 p. (in Russian).

Forstreuter, Kurt. Preussen und Russland von den Anfängen des Deutschen Ordens bis zu Peter dem Großen [Prussia and Russia from the Founding of the German Order up to Peter the Great]. Göttingen; Berlin; 
Frankfurt: Gottingen u. a.: Musterschmidt-Verl., 1955. (Göttinger Bausteine zur Geschichtswissenschaft. Vol. 23). 257 p. (in German).

Kappeler, Andreas. Ivan Groznyj im Spiegel der ausländischen Druckschriften seiner Zeit. Ein Beitrag zur Geschichte des westlichen Russlandbildes [Ivan the Terrible in the Mirror of Foreign Print of the Time: A Study of the Image of Russia in the West]. Bern: Herbert Lang; Frankfurt am Main: Peter Lang Publ., 1972. (Geist und Werk der Zeiten. Arbeiten aus dem Historischen Seminar der Universität Zürich. No 33). 298 p. (in German).

Laucevičius, Edmundas. Popierius Lietuvoje XV-XVIII a. Atlasas [Paper in Lithuania. Album]. Vilnius: Mintis Publ., 1967. 577 p. (in Lithuanian).

Lulewicz, Henryk. Gniewów o unię ciag dalszy: Stosunki polsko-litewskie w latach 1569-1588 [Further Disputes on the Union: Polish-Lithuanian Relations in 1569-1588]. Warszawa: Neriton - Instytut Historii Polskiej Akademii Nauk Press, 2002. 457 p. (in Polish).

Lurye, Yakov Solomonovich. Novye dannye o posol'stve Sugorskogo i Arcybasheva v 1576 g. [New data on the embassy of Sugorsky and Artsybashev in 1576], in Istoricheskie zapiski. 1948. № 27. Pp. 291-300. (in Russian).

Poe, Marshall. Foreign Desriptions of Muscovy: An Analytic Bibliography of Primary and Secondary Sources. Columus, Ohio: Slavica Publishers, 1995. 230 p.

Schellhaß, Karl. Zur Legation des Kardinals Morone (1576; Moskau, Bayern) [On Cardinal Morone's Embassy, 1576 (Moscow, Bayern)], in Quellen und Forschungen aus Italien. Archiven und Bibliotheken. Rom: Verlag von Loesher \& Co Publ., 1910. № 13. Pp. 273-376. (in German). 